\title{
"Kui ongi tõsi, siis ise süüdi!" Seksuaalvägivallaga seonduvad stereotüübid ühe Eesti laste ja noorte veebifoorumi teemaalgatustes ja vastustes
}

\author{
Simone Eelmaa \\ Tartu Ülikooli sotsioloogia doktorant \\ simone.eelmaa@ut.ee \\ Maria Murumaa-Mengel \\ Tartu Ülikooli sotsiaalmeedia lektor \\ maria.murumaa@ut.ee
}

\begin{abstract}
Teesid: Artiklis anname ülevaate sellest, kuidas lapsed ja noored veebifoorumite vahendusel seksuaalvägivalla ohvriks langemise osas abi ja tuge otsivad ning millised on sellistele postitustele järgnevad vastukajad. Meie fookus on eelkõige sellel, millist rolli mängivad vägistamismüüdid ja soostereotüübid nii teemaalgatajate kui ka vastajate käsitlustes seksuaalvägivallast, ohvritest ja toimepanijatest. Valitud tekste analüüsides kombineerisime diskursiivpsühholoogilise analüüsi ja kvalitatiivse temaatilise sisuanalüüsi võtteid. Tulemustes kirjeldame näiteks selliseid stereotüüpe nagu tõeline ohver, reaalne vägistamissituatsioon ja tõeline toimepanija. Veebifoorumis osalejate konstrueeritud repertuaarides peegelduvad valusa selgusega ühiskondlikult domineerivad väärarusaamad seksuaalvägivallast.
\end{abstract}

Märksõnad: laste seksuaalne väärkohtlemine, ohvrisüüdistamine, seksuaalvägivald, stereotüübid, vägistamismüüdid

\section{Sissejuhatus}

Seksuaalvägivalla puhul on tegu vägivallaga, mis on paljuski peidetud ning alaraporteeritud, kuid sellegipoolest viitab olemasolev statistika sellele, et väga paljud inimesed puutuvad seksuaalvägivallaga elu jooksul ühel või teisel moel kokku (Kloppen et al. 2016). Eesti uuringutes on näiteks leitud, et umbes $30 \%$ Eesti lastest ja noortest on seksuaalse väärkohtlemise tõttu kannatama pidanud ning umbes $10 \%$ on isiklikult kogenud seksuaalvägivalda (Soo et al. 2016). Selliste traumaatiliste kogemuste puhul on määrava tähtsuse ja rolliga laiemad ühiskondlikud seksuaalvägivalla mõistmise ja mõtestamise viisid, muuhulgas 
see, kuidas ümbritsevad juhtunule reageerivad ning kuidas nähtusest avalikes diskussioonides räägitakse.

Sotsiaalse elu struktuuri osaks on müüdid - kollektiivselt jagatud lood, mida erinevad kultuurid kasutavad, selgitamaks ja mõtestamaks reaalsuse ja igapäevaelu erinevaid tahke. Seejuures esitatakse müütidesse põimitud väärtusi, vastandusi ja võimusuhteid loomulikena, peites nii müütide sotsiaalset konstrueeritust, ajaloolist kujunemislugu ja sotsio-poliitilist mõju (Fiske 2010). Stereotüüpe - sageli vääratel alustel ja liialdustel põhinevaid üldistusi ning vääruskumusi - võib vaadelda kui suurte müütide ehituskive. Nii näiteks on meie artikli keskmes vägistamismüüdid (Adolfsson 2018; Payne et al. 1999) kui raamistused, mille moodustavad erinevad väärarusaamad vägistamisest ning mille juured on ühiskondlikes kultuurilistes arusaamades soo ja seksuaalsuse kohta (Anderson \& Doherty 2007). Vägistamismüütides on põimunud soostereotüübid (Basow 1992; Lips 2017), seksuaalsed stereotüübid ja stsenaariumid (Sun et al. 2016) ning ohvri staatusega seonduvad stereotüübid (Anderson \& Doherty 2007). Seksuaalvägivalla puhul võivad need stereotüübid puudutada seda, milline tüüpiline vägistamissituatsioon on või "olema peaks" (nii rõlgelt kui see ka ei kõlaks), et seda defineeritaks vägistamisena. Laialt levinud stereotüüpide ehk vääruskumuste seast leiame väiteid, et alkoholijoobes naised on juhtunus ise süüdi või vastutavad vähemalt osaliselt; et ainult naised on seksuaalvägivalla ohvrid; et ainult mehed on toimepanijad; et vägistamised on äärmiselt vägivaldsed; või et toimepanija on ohvrile enamasti võõras (Reynolds 2017). Vägistamismüütidel ja stereotüüpidel on mõju sellele, kuidas sotsiaalses või ka juriidilises mõttes käsitletakse ohvreid ja ohvri süüd ning teo toimepanija õigustamise ulatust (Ward 1995; Ayala 2018).

Stereotüübid on ajas võrdlemisi püsivad, kuna need on komplekssete sotsiaalsete nähtuste lihtsustatud representatsioonid ning aitavad meil situatsioonide, nähtuste ja inimestega kiiremini ja tõhusamalt toime tulla (Pickering 2007). Keel, olgu siis kirjalik, suuline või sootuks audiovisuaalne, (taas)toodab sotsiaalseid struktuure, sealhulgas stereotüüpe ja müüte ning seetõttu peame oluliseks vaadelda süsteemselt ja põhjalikult, kuidas müüte üles ehitatakse ja/ või toimimas hoitakse, keskendudes eelkõige seksuaalvägivalda raamistavatele diskursiivsetele praktikatele. Artikli aluseks oleva uuringu eesmärk oli kaardistada ühe Eesti veebifoorumi tekstide põhjal vägistamismüütide esinemist ja taasloomet nii seksuaalvägivalla ohvrite poolt algatatud abiotsimise kontekstis kui ka teiste foorumikasutajate vastustes. Uuringu alusandmed pärinevad lastele ja noortele suunatud Eesti veebifoorumist, kus saab arutleda paljudel teemadel, sh ka seksuaalvägivalla üle.

Eelnevalt on Eestis seksuaalvägivalla temaatikat akadeemiliselt uuritud peamiselt kvantitatiivsete uurimismeetoditega (Soo 2006; Soo et al. 2016; Minn 
2018) või ekspertintervjuudega (Touart 2013), aga uuritud on ka seksuaalvägivalla meediarepresentatsioone (Kivisalu 2019). Valdavalt on uuringud õigusteadusele (Talts 2013; Kurs 2018; Paal 2019) või psühholoogiale (Taliväting 2018) omastes raamistustes. Meie uurimus püüab lisada kvalitatiivse teksti (süva)analüüsiga nähtavaks muutuvaid sotsiokultuurilisi detaile.

Seksuaalvägivalla puhul on terminoloogiline väli lai ja kohati puuduvad ühtsed arusaamad, millest ja mis tähenduses kõneldakse. Nii räägitakse paralleelselt seksuaalvägivallast, vägistamisest, ahistamisest ja väärkohtlemisest. Selguse mõttes toome siinkohal välja peamised definitsioonid, millest käesolevas artiklis lähtume. Vägistamist defineeritakse igasuguse tahtevastase seksuaalvahekorrana, mille osaks võib olla vägivald või ohvri seisundi ärakasutamine, kui ohver ei ole võimeline vastupanu osutama või toimunust aru saama (Karistusseadustik § 141). Seksuaalvägivald on tunduvalt laiem mõiste, Maailma Terviseorganisatsiooni (2013) definitsiooni kohaselt on seksuaalvägivald ka igasugune tahtevastane seksuaalvahekorda astumise katse, soovimatud seksuaalse alatooniga märkused, lähenemiskatsed või muul moel isiku seksuaalsuse vastu sunni abil ja ükskõik millises kohas (kodus, tööl või mujal) toimepandud teod, olenemata teo toimepanija ja ohvri suhtest. Laste seksuaalne väärkohtlemine on võimu, seksuaalsete või muude vajaduste rahuldamise eesmärgil toime pandud seksuaalse sisuga kontaktne või mittekontaktne tegevus täiskasvanu või teise lapse poolt, kes vanuse või arengutaseme tõttu on lapsega vastutus-, usaldus- või võimusuhtes (ibid.). Siin käsitleme seksuaalvägivalda ja laste seksuaalset väärkohtlemist samatähenduslikult, kuna uuringu kitsamas fookuses on just alaealiste poolt veebifoorumisse postitatu. Etteruttavalt võib öelda, et meie valimis domineerisid selgelt vägistamise definitsioonile vastavate olukordade kirjeldused ja neile järgnevad arutelud.

\section{Seksuaalvägivallaga seonduvad stereotüübid}

Kuigi stereotüüpide kujunemist ja käsitlemist mõjutavad mitmed protsessid (nt kognitiivsed ja afektiivsed) ja tihtilugu on tegu erinevate protsesside koosmõjuga, kujunevad stereotüübid valdavalt sotsiaalsetes kontekstides. Stereotüüpide kujunemist mõjutavad nii individuaalsed faktorid, kultuuriline kontekst laiemalt ja meediarepresentatsioonid kui ka sotsiaalsed interaktsioonid, laste ja noorte puhul eelkõige lapsevanemad ja eakaaslased (Macrae et al. 1996: 41-79). Lapsed omandavad stereotüüpseid arusaamasid väga varakult (Sherman et al. 2016: 559), näiteks soostereotüübid võivad negatiivselt mõjutada juba kuueaastase lapse käsitlusi iseendast ja ümbritsevast maailmast (Bian et al. 2017; Stone et al. 2015). 
Seksuaalvägivalla tajumisel ja mõtestamisel on kandev roll soo- ja seksuaalsetel stereotüüpidel, kuid märkmisväärsel hulgal inimestest on paraku ka personaalne reaalne seksuaalvägivalla kogemus, ning sageli on ohvriteks lapsed ja noored. Erinevad uuringud näitavad, et seksuaalvägivalda kogenutest $12 \%$ puhul on see juhtunud enne viieteistkümnendat eluaastat (Euroopa Liidu Põhiõiguste Amet 2014). Põhjamaades on laste seksuaalse väärkohtlemise levimus poiste puhul vahemikus 3-23\% ning tüdrukute puhul 11-36\% (Kloppen et al. 2016). Eesti tüdrukute puhul on leitud, et kuni $18 \%$ on enne kahekümnendat eluaastat kogenud vähemalt ühte seksuaalvägivalla situatsiooni (Soo et al. 2016) ning Eestis on valdav osa raporteeritud seksuaalkuritegude ohvritest alaealised - 2018. aastal olid 87\% ohvritest alaealised, kannatanu keskmine vanus oli 12 aastat ning kõige noorem ohver oli noorem kui üks aasta (Ahven et al. 2019).

Paljuski kujuneb inimeste, sh ka laste ja noorte arusaam seksuaalvägivallaga seotud stereotüüpidest üldjuhul selliseks nagu neid perekonnas, meedias või laiemalt ühiskonnas käsitletakse. Ühiskondlikul tasandil on seksuaalvägivalla ohvrites kahtlemine või nende süüdistamine väga levinud. Näiteks viis aastat tagasi Eestis läbi viidud uuringus selgus, et $47 \%$ elanikest süüdistasid juhtunus naissoost seksuaalvägivalla ohvrit (TNS Emor 2014), kaks aastat hiljem läbi viidud kordusuuringus oli see osakaal veidi väiksem, kuid siiski $42 \%$ (TNS Emor 2016). Usutakse näiteks, et vägistamisohvrid on kergemate elukommetega ning alkoholijoobes ohvrid on vähemalt osaliselt juhtunus ise süüdi (Eesti Seksuaaltervise Liit 2014; Socio 2016).

Üks teooria, mis aitab mõista vägistamismüütide ja seksuaalvägivallaga seonduvate stereotüüpide püsivust, on õiglase maailma hüpotees (Lerner \& Matthews 1967; Lerner \& Miller 1978) ehk uskumus, et maailm on õiglane koht ja inimesed saavad just seda, mida nad väärivad. See on teooria, mis on eelnevalt leidnud rakendust just ohvrisüüdistamise fenomeni analüüsis (Hammond et al. 2011; Strömwall et al. 2013; Yamawaki 2009). Õiglase maailma hüpoteesi kohaselt usuvad inimesed üldjuhul, et mitte üksnes seksuaalvägivalla, vaid ükskõik millise kuriteo või ebaõigluse puhul on ohver olnud ise süüdi selles, mis nendega juhtunud on, mistõttu on nendega juhtunu neile vääriline "tasu" (Strömwall et al. 2013; Yamawaki 2009). Teisalt on aga läbi viidud uuringuid, mille kohaselt õiglase maailma hüpotees ei mõjuta ohvrisüüdistamist kui diskursiivset praktikat (Hammond et al. 2011) ning pelgalt õiglase maailma hüpotees ei suuda ohvrisüüdistamist täielikult selgitada (Bruggen \& Grubb 2014; Gravelin 2018).

Rohkem toetust on leidnud kausaalse atributsiooni teooria ehk põhjuslikkuse omistamine (Shaver 1986). Atributsiooniteooria (defensive attribution theory) kohaselt kasutavad inimesed teatud laadi uskumusi kilbina, kaitsmaks ennast 
mõtte eest, et nemad võiksid langeda ohvriks (või kellelegi ise kannatusi põhjustada). Selle teooria kohaselt on ohvrisüüdistamine seotud tajutud sarnasuste ja ohvriga samastumisega (Shaver 1986). Mida sarnasemaks end ohvriga peetakse, seda vähem ohvrit süüdistatakse (Grubb \& Harrower 2008). Sama on rõhutatud stereotüüpide puhul laiemalt, näiteks Michael Pickering (2007) toob välja, et kõikvõimaliku stereotüpiseerimise oluliseks tunnuseks, distantseerivaks mehhanismiks on kontrasti rõhutamine iseenda ja stereotüpiseeritava vahel. Varasemalt on seksuaalvägivalda puudutavates uuringutes leitud, et tajutud sarnasus vägistamisohvriga ennustab märkimisväärselt süü omistamist nii täiskasvanute kui alaealiste vägistamise puhul (Davies et al. 2009). Mehed süüdistavad naissoost ohvreid enam kui naised, sest nad samastuvad tüüpilise seksuaalkuriteo ohvriga vähem (Davies et al. 2009).

Ohvrisüüdistamise põhjused võib jaotada kaheks - karaktereoloogilised ja käitumuslikud. Esimese puhul seostatakse süüd muutumatute teguritega (välimus või isiksus) ning teise puhul muutuvate teguritega (riietus, käitumine või valikud) (Janoff-Bulman 1979). Naissoost ohvritele omistatakse käitumuslikku süüd sagedamini kui meessoost ohvritele. Mehed omistavad karaktereoloogilist süüd naissoost ohvritele enam kui meessoost ohvritele, samas naised omistavad karaktereoloogilist süüd võrdselt nii mees- kui ka naissoost ohvritele (Anderson 1999). Naissoost ohvreid süüdistatakse üldiselt enam kui meessoost ohvreid ning karaktereoloogilist süüd omistatakse samuti enam naissoost ohvritele (Howard 1984).

Ohvriga seotud tegurite kõrval on uuritud ka kõrvalseisjaga seotud faktoreid, mis mõjutavad ohvrisüüdistamise esinemist ja ulatust (Bruggen \& Grubb 2014; Franklin \& Menaker 2015). Mitmed uuringud on tuvastanud, et mida lähedasem suhe on toimepanijal ohvriga olnud, seda enam süüd ohvrile omistatakse (Gravelin et al. 2018; Yamawaki 2009). Nagu varasemalt mainitud, on süüdistaja sugu oluline tegur - mehed süüdistavad ohvreid naistest enam. Lisaks süüdistavad ohvreid sagedamini inimesed, kes pooldavad traditsioonilisi soorolle, usuvad seksuaalvägivallaga seotud müüte ning omavad kesisemaid teadmisi kehtivast seksuaalvägivallaga seotud õigusest ja näiteks ka vägistamise definitsioonist (Patel 2009). Ohvri süüdistamisest hoiduvad seega pigem need, kellel on soorollide osas egalitaarne hoiak, paremad teadmised sellest, millised on seksuaalvägivallaga seotud müüdid ja mis on reaalsus ning parem arusaam sellest, mis kvalifitseerub vägistamiskuriteoks. Lisaks on Meghna Nalinkumar Patel (2009) toonud välja, et ohvrisüüdistamisest hoiduvad need, kes on ise seksuaalvägivalda kogenud.

Veel on uuritud, kuidas mõjutab süü omistamist toimepanijate arv. Kerstin Adolfsson (2018) leidis, et grupivägistamise ohvritel nähakse suuremat süüd kui ohvritel, keda vägistas üks isik. Samas uuringus leiti, et ohvri süüdistamist 
põhjustavad pigem isiklikud uskumused kui konkreetse vägistamisega seotud faktid. See tähendab, et kuigi ohvrit süüdistades toetutakse üldiselt vägistamissituatsiooniga seotud faktidele (näiteks kus see toimus või mida ohver tegi), on need lihtsalt retoorilised vahendid, mitte reaalsed põhjused, miks ohvrit süüdistatakse.

Ohvrisüüdistamist esineb vähem, kui seksuaalvägivalla all kannataja vastab nn tõelise ohvri stereotüübile. See on sotsiaalne konstruktsioon ohvrist, kes ei ole juhtunus süüdi, "ei väärinud" seda, mis temaga juhtus ning kes väärib seega nii kaastunnet kui ka abi. Tõelise ohvri stereotüüpi mõjutavad karakteroloogilised ja käitumuslikud aspektid, kuid ka näiteks ohvri suhe toimepanijaga, vägivalla ulatus, vigastuste esinemine, politseisse pöördumise aeg ja ohvri varasem elustiil (Stewart et al. 1996). Need stereotüübi komponendid mõjutavad nii ohvri süüdistamist kui ka tema uskumist (Schuller et al. 2010; Krahé et al. 2008).

Kuigi reaalsuses peaks teo vägistamisena käsitlemiseks lähtuma vägistamiskuriteo juriidilisest definitsioonist, mängivad ohvriga seonduvad stereotüübid olulist rolli ka siinkohal. Seda eriti angloameerika kohtusüsteemis, kus kasutatakse õigusemõistmisel vandekohtute süsteemi. Näiteks vägistamiste puhul, kus ohver ja teo toimepanija teineteist tunnevad, käsitleti toimepanijat sagedamini teos süüdi olevana, kui ohver vastas stereotüüpilise ohvri "kriteeriumitele", ning toimepanijat nähti sagedamini süütuna, kui ohver ei vastanud stereotüüpilisele kuvandile (McKimmie et al. 2014). Samuti usuvad vandekohtunikud ohvrit sagedamini kui ohver on emotsionaalne (pisarates, endast väljas) võrreldes ohvritega, kes on rahulikud ja näitavad välja vähem emotsioone (Schuller et al. 2010). Tõelise ohvri stereotüüpi kasutatakse ka strateegiana, ehitamaks üles ohvrist ebausaldusväärset kuvandit vandekohtu ees, näiteks lahates ohvri elustiili või varasemaid seksuaalsuhteid (Krahé et al. 2008).

Peale selle süüdistavad ohvrid end sageli ise. Käitumuslik enesesüüdistamine on seotud kontrolliga ning uskumisega, et tulevikus on võimalik negatiivset tagajärge vältida. Samas on karakteroloogiline enesesüüdistamine seotud enesehinnanguga ja uskumisega, et juhtunu oli kuidagi ära teenitud. Ohvrite enesesüüdistamise puhul on käitumuslik omistamine tavapärasem kui karakteroloogiline, viimast aga esineb enam depressioonis ohvrite puhul (Janoff-Bulman 1979). Lapsepõlves kogetud seksuaalse väärkohtlemise puhul on enesesüüdistamine üks oluline takistus abi otsimisel (Alaggia et al. 2019). Teraapia on aidanud vähendada hirmu ja enesesüüdistamist (Nelson 2019), mistõttu on õigeaegne abi kriitilise tähtsusega. 
Politseilt või vaimse tervise spetsialistidelt abi otsimine on aga seksuaalvägivalla, eriti vägistamisohvrite puhul harv (Wolitzky-Taylor et al. 2011). Varasemad uuringud näitavad, et kui seksuaalvägivalla ohvrid juhtunust kellelegi või kellegagi räägivad, on negatiivsed reaktsioonid (süüdistamine ja stigmatiseerimine) tavapärased, seda eriti formaalses kontekstis nagu politsei poole pöördudes või kohtus (Filipas \& Ullman 2001; Greeson et al. 2016). Ühe lastele keskenduva uuringu kohaselt oli peamine põhjus, miks lapsed seksuaalsest väärkohtlemisest ei rääkinud, kartus, et neid ei usuta, kui nad oma kogemustest räägivad (McElvaney et al. 2014). Ka Kadri Soo, Made Laanpere, Hedda Lippus ja Kai Part (2015) tõid välja, et enamasti seksuaalvägivalla alaealised ohvrid juhtunust küll kellelegi ei räägi, kuid teisalt tunnevad nad kõige enam puudust kommunikatiivsetest toimetulekustrateegiatest - et saaks kellegagi juhtunust rääkida ja saada emotsionaalset tuge.

Näost näkku seksuaalvägivallast rääkimine võib olla ohvritele emotsionaalselt väga keeruline, eriti kui ühiskonnas domineerivad ohvrisüüdistamise diskursused. Erinevad veebiplatvormid avavad juhtunust rääkimiseks uusi võimalusi. Laste ja noorte puhul on oluline märkida, et internetikasutuse aktiivsus on nooremates vanuserühmades juba pikemat aega olnud peaaegu sajaprotsendiline (Statistikaamet 2019), see tähendab, et erinevatel platvormidel osalemine on suure osa noorte igapäevaelu pärisosa. Mõned aastad tagasi läbi viidud uuring tuvastas, et noored otsivad seksi ja seksuaalsusega seotud küsimustele vastuseid kõige sagedamini internetist (Soo et al. 2015). Veebifoorumites on sageli võimalik jääda anonüümseks, mis on meie tundliku ja emotsionaalselt ränkraske teema puhul ülioluline nüanss, kuna veebiplatvorme on seetõttu võimalik kasutada nn pihitooli-tehnoloogiana (Friesen 2017), kus kasutajal on võimalus muresid jagada, otsida abi või seda ise pakkuda. Kirjalikus veebisuhtluses ei pea muretsema vahetute reaktsioonide nähtavuse pärast, saab valida oma tempo ja aja, tekste saab läbi mõelda ning toimetada, mis kõik kokku võimestab diskussioonis osalejaid, andes neile rohkem kontrolli esitatavate narratiivide üle (Mann \& Stewart 2000). Teisalt aga (taas)luuakse veebipõhistes asünkroonselt ja sünkroonselt toimivates interaktsioonides sotsiaalseid struktuure ja norme, jutustatakse lugusid ja kinnistatakse müüte ning stereotüüpe (sealhulgas ka vägistamismüüte ja soo- ning seksuaalseid stereotüüpe). 


\section{Uuringu valim ja meetodid}

Oma uuringus otsime vastuseid kahele uurimisküsimusele: Millised stereotüübid esinevad alaealiste seksuaalvägivalla ohvrite abi otsimise püüetes? Milliseid stereotüüpe konstrueerivad teised foorumis osalejad oma vastustes?

Meie uuringu tekstid on pärit ühest eestikeelsest veebifoorumist, mis on suunatud eelkõige nooremale kasutajaskonnale. Tegemist on veebifoorumiga, kus on registreeritud liikmeid kokku üle 30 000, kuid osaleda ja alafoorumitele ligi pääseda on võimalik ka registreerumata ja postitada külalisena. Alafoorumid keskenduvad väga paljudele erinäolistele teemadele, kuid eraldi alateemad on seksuaalvägivalla kohta, mis on ka käesoleva uuringu alguspunktiks. Valitud tekste analüüsisime peamiselt diskursiivpsühholoogilise analüüsi põhimõtteid rakendades (Edwards \& Potter 1992; Potter \& Wetherell 1987), kuid erinevates rollides olevate inimeste manifestsete interaktsioonide kaardistamisel leidsime abi ka kvalitatiivse temaatilise sisuanalüüsi võtetest (Braun \& Clarke 2006). Näiteks jälgisime analüüsi käigus seoseid, mida võis märgata abi otsimise kirjelduste ja järgnenud vastuste vahel, otsides mustreid ja sõltuvusi erinevate osapoolte dialoogis. Diskursusanalüüsile omane detailsus ja teksti süvenemine oleks takistanud suurest andmehulga skemaatilise ülevaate tegemist, kuid Virginia Brauni ja Victoria Clarke’i (2006) temaatilise sisuanalüüsi etapid 2-4 (esialgne kodeerimine, teemade otsimine ja üksteisest eristuvate teemade süstematiseerimine teemakaardiks) sobisid selle eesmärgi täitmiseks hästi.

Uuringudisaini esimese osa fookuses on seksuaalvägivalda kogenute poolt konstrueeritavad diskursused - mis on postitamise eesmärk, kuidas juhtunut kirjeldatakse ja oma kogemusi tõlgendatakse. Konstrueeritud diskursused on esitletud tõlgendusrepertuaaridena, mis on diskursiivpsühholoogia diskursusanalüüsi metodoloogiast pärit mõiste. Tõlgendusrepertuaar on järjekindel ja sidus viis rääkida mingitest sündmustest, isikutest või objektidest (Potter 1996). Repertuaare võib vaadelda kui mõiste- ja mõtlemise konstruktsioone, mille abil kõnelejad ehitavad erinevaid versioone sündmustest, nähtustest ja kognitiivsetest protsessidest (McKenzie 2005). Ühe repertuaari erinevate versioonide puhul esineb Pamela McKenzie (2005) sõnul siiski süstemaatiline koherentsus, mistõttu sellistes diskursusanalüüsides otsitaksegi pigem sarnasusi kui variatsioone.

Et leida meie uurimisküsimuste seisukohalt olulisi ja kõnekaid tekste, võtsime vaatluse alla seksuaalvägivalla-teemalised alafoorumid, kus oli kokku üle 330 teemaalgatuse (seksuaalvägivalla teemafoorumi alla tehtud uus postitus, mille alla tekib vastustest kronoloogiliselt täienev dialoog). Kuna diskursusanalüüs ei ole kvantitatiivne uurimismeetod, pigem on selle meetodi abil näha 
süvitsi teksti “sisse”, siis lugesime küll läbi kõik postitused ja vastused, kuid analüüsi fookustamiseks kitsendasime valimit mitme võtte ja kriteeriumiga:

- postituse sisus pidi olema isiklikult kogetud seksuaalvägivalla või selle ähvarduse kirjeldus,

- postituse sisus pidi sisalduma viide sellele, et seksuaalvägivald on juhtunud alaealisega,

- postituse sisus pidi sisalduma viide sellele, et autor on ka postituse koostamise hetkel alaealine,

- postitusel pidi olema vähemalt kaks erineva kasutaja kirjutatud vastust.

Lõplikku valimisse jäi nende kitsenduste rakendamise järel 28 postitust ajavahemikus 2007-2018. Postituste pikkused ulatuvad paarist lausest (lakooniline probleemikirjeldus) mitmekümne lauseni (detailsem juhtumikirjeldus).

Üldjuhul tehti postituseks eraldi konto, samuti kasutati külalisena postitamise võimalust. Peresisese seksuaalvägivalla puhul postitati alati külalisena ning kirjeldused olid enamasti detailivaesed ja konkreetsemad võrreldes teiste juhtumitega. See ei olnud küll valimi koostamise kriteeriumiks, kuid lõplik valim koosneb vaid naissoost autorite postitustest, mis on juba selles uuringuetapis kõnekas tulemus.

Meie uuringu valimisse kuulusid postitused, mille puhul autorid kirjeldasid ennast kui alaealist. Sellele võis viidata konkreetne vanuse sedastamine ("olen 15aastane tüdruk"), aga ka muud viited, nagu näiteks mitmendas klassis teemaalgataja õpib või kui selgitati, et toimepanija on juba täiskasvanu. Valimis olnud postituste autorid olid enda sõnul seksuaalvägivalla asetleidmisel alaealised, vanuses 5-17. Alaealise ohvri keskmine vanus valimis on 12,2 aastat. Oleme teadlikud, et veebisuhtluse puhul on võimalik end esitleda oma tegelikust minast erinevana (nt muuta enesepresentatsioonis oma sotsiodemograafilisi karakteristikuid) ning ka räägitud lugude tõesust ei ole võimalik kontrollida. Meie teema puhul aga tekitaks rohkelt sisemisi ja väliseid väärtuskonflikte, kui rõhutaksime uuringu tulemusi esitades läbivalt valeinfo esitamise võimalikkust ning annaksime seeläbi oma väikese, kuid märgiliselt tähendusliku panuse seksuaalvägivalla ohvrite mitteuskumise pikka traditsiooni.

Enamasti kirjeldasid autorid postitustes vägistamisi (20 juhtumit, neist kolm kirjeldasid grupiviisilist vägistamist), mille kodeerimiseks kasutasime käesoleval hetkel Eestis kehtivat vägistamise juriidilist definitsiooni (Karistusseadustik $\S 141$ ). Valimisse kuuluvates teemaalgatustes on kirjeldatud ka vägistamiskatset, seksuaalset ahistamist, seksuaalvägivallaga ähvardamist ja muid seksuaalse iseloomuga tegusid (näiteks veebis toimunud seksuaalset väärkohtlemist ja laste seksuaalset ahvatlemist ehk online grooming'ut). 
Valimis olnud postitusi oli vaadatud kokku enam kui 178000 korda, keskmiselt ca 6300 vaatamist postituse kohta, seega on tekstide lugejaskond kindlasti suurem kui veebifoorumi vastuste kaudu nähtavaks muutunud auditoorium. Kokku oli aga 28 postituse peale 361 vastust, millest kategoriseerimise käigus umbes kolmandik vastuseid uuringuvalimist välja jäid. Valimist jäid välja vastused, mis ei sisaldanud sõnu (nt koosnesid ainult ühest või mitmest emotikonist) ning need, mis ei olnud enam teemakohased (tekkisid teemavälised sopistunud diskussioonid nagu näiteks teiste foorumikasutajate grammatilised oskused ja puudujäägid).

Analüüsi teise osa moodustasidki valimisse kuuluvate postituste vastused ehk - fookuses on ka teiste inimeste reaktsioonid seksuaalvägivalla ohvrite kirjeldustele ja abipalvetele. Vastajad kirjutasid enamasti oma püsikonto alt, seda ka ebaviisakate ja solvavate vastuste puhul. Umbes pooled kontodest on avalikud ning nende profiilidele oli võimalik ligi pääseda. Kättesaadava info põhjal saab välja tuua, et vastajateks olid nii täiskasvanud kui ka teised alaealised.

Nagu öeldud, oleme käesolevas uurimuses kasutanud peamise meetodina tõlgendusrepertuaaride analüüsi, mis kuulub diskursiivpsühholoogia koolkonda (Edwards \& Potter 1992; Potter \& Wetherell 1987). Tegu on ühe diskursusanalüüsi vormiga, milles vaadeldakse, kuidas kasutatakse keelt ja kõnet, millisel eesmärgil ja mis funktsiooniga, mõistmaks näiteks inimeste hoiakuid või seisukohti. Diskursusanalüüs laiemalt on meetod, mis võimaldab analüüsida keelt kui sotsiaalset praktikat, sotsiaalsetes interaktsioonides peituvaid ideoloogilisi seisukohti (Gibbs 2015). Need seisukohad ja diskursused võivad olla avalikud või peidetud, teadvustatud või teadvustamata, juhuslikud või strateegilised. Veebifoorumi postituste analüüsis keskendusime diskursuste struktuuridele (temaatilised repertuaarid ja mustrid, ideoloogilised seisukohad ning retoorilised struktuurid). Tõlgendusrepertuaarid pealkirjastasime kõige iseloomulikuma tsitaadi rekonstruktsioonina. Kokku konstrueerisime kuus tõlgendusrepertuaari, millest kolm keskenduvad ohvri enesekohastele repertuaaridele ning kolm vastajate reaktsioonides ilmnevatele repertuaaridele.

Kuna tegemist on äärmiselt tundliku teemaga, tekstid on veebis otsitavad ja kättesaadavad ka väljaspool uuringut, otsustasime pärast pikka kaalutlemist tulemuste esitusel mitte kasutada täpseid tsitaate, mis võimaldaksid järjest kasvava võimekusega otsingumootoreid kasutades jõuda originaaltekstideni ning seeläbi põhjustada veebifoorumis osalejatele põhjendamatud kannatusi ja soovimatut tähelepanu. Ehkki diskursusanalüüsi üheks tugevuseks on just keelenüansside interpretatsioon ja analüüs, peame selle asemel rõhutama raamistavate diskursuste märkamist ja kirjeldamist laiemalt. Püüame uurijatena eetilistel kaalutlustel vältida inimeste digitaalsesse jalajälge panustamist. 
Inimesed jagavad küll veebifoorumites ja sotsiaalmeedias ohtralt privaatset infot, kuid selle teabe jagamine teises või uues kontekstis võib tähendada nende privaatsuse rikkumist (Markham 2012: 337). Internetiuurija Annette Markham (2012) on kõnelnud andmete fabritseerimisest kui eetilisest uurijapraktikast, mille käigus töödeldakse ja vormistatakse ümber analüüsi alusandmed. Püüame neid põhimõtteid järgida ka selles artiklis, rekonstrueerides illustreerivad tekstinäited võimalikult algse konteksti ja sõnastuse lähedaselt, kuid hägustada neid siiski piisavalt, et püüda suurendada veebifoorumites osalejate anonüümsust ja konfidentsiaalsust.

\section{Seksuaalvägivalda kirjeldavad teemaalgatused ja abipalved}

\section{"Palun aidake, ma ei julge sellest kellelegi rääkida" - ohvrite püüded dialoogi alustada ja nõu saada}

Peaaegu kõigi teemaalgatuste puhul oli mainitud, et tegu on esimese korraga juhtunust kellelegi rääkida. See ei välista varasemaid püüdlusi või katsetusi juhtunust rääkida, kuid valdavalt oli tegu esimese korraga seksuaalvägivalla toimumist konkreetselt tunnistada ja abi küsida. Sarnaseid tulemusi on saanud ka teised uurijad - lapsepõlves toimunud seksuaalse väärkohtlemise puhul on leitud, et umbkaudselt 55-70\% ohvritest ei räägi enne täiskasvanuks saamist juhtunust kellelegi (London et al. 2008). Sageli puuduvad füüsilised asitõendid ning tegu on äärmiselt latentse kuriteoliigiga, mistõttu võib juhtunust kellelegi rääkimine olla üks olulisemaid viise seksuaalse väärkohtlemise avastamiseks. On leitud, et lapseeas toimunud seksuaalsest väärkohtlemisest rääkimine on pigem mitmeosaline ja keeruline protsess kui ühekordne sündmus, ning esmaste abiotsimise püüete vastused määravad selle, kas üldse ja kuidas traumaatilise kogemusega toime tullakse (Reitsema \& Grietens 2016).

Umbes pooled postitustest kirjeldasid seksuaalvägivallajuhtumeid, mis olid toimunud hiljuti, viidates ajalisele mõõtmele lausetega nagu "eile läksime", “eelmisel nädalavahetusel” või "sellest on kaks nädalat möödas". Ülejäänute puhul oli tegemist juhtumitega, mis olid toimunud juba mõnda aega tagasi, seitsme postituse puhul isegi mitu aastat tagasi. Aastaid hiljem postitati eeskätt siis, kui ohver oli juhtunu toimumisel väga noor, orienteeruvalt 5-10aastane. Nende teemaalgatuste puhul oli selgem, et autorit valdasid segased tunded, juhtunut oli valus meenutada ja mõnikord mäletati juhtunust vaid üksikuid mälupilte. Üldjuhul on need mälupildid aga postitajaid juba enne veebifoorumisse pöördumist pikalt painanud, sest postituste algusesse põimiti tihtilugu 
väljendeid "see on mind kogu aeg kummitanud", "lõpuks kirjutan ära", "see on mul pidevalt meeles". Autorid tõid korduvalt välja, et jutt võib olla segane, sest meenutada on valus või nad ei mäleta täpselt kõike. Sageli väljendati soove ja vajadusi, mis seonduvad kommunikatiivsete toimetulekustrateegiatega lihtsalt oma mure hingelt ära rääkida või saada nõu selle kohta, kuidas abi küsida (kuhu pöörduda, kuidas emale rääkida jne):

Ma näen mõnikord neid kujutluspilte oma unenägudes ja see on kohutav. Sellest on möödas juba umbes viis aastat, aga ma ei oska sellest oma emale kuidagi rääkida.

Postituste alguses olevad väljendid nagu "tahan ennast tühjaks kirjutada" näitavad, et seksuaalvägivallajuhtumid "täidavad" ohvri kogu mõtte- ja tundemaailma. Painavad unenäod on tihtipeale ajendiks, mis noored postitama toob. Kuna enamasti ei ole lapsed ja noored nende vastu suunatud vägivallast kellelegi rääkinud, siis keerlevad juhtunu detailid peas nii ärkvel olles kui ka magades:

Ma ei tea, mida teha, palun aidake mind, see juhtus küll tükk aega tagasi, aga see kõik on mul veel meeles - kõik liigutused, mis ta tegi ja kõik, mida ta ütles. Ma näen pidevalt seda unes ja see on õudne.

Ohvrid pöörduvad oma murega foorumisse, sest soovivad tunda, et nad pole üksi, jagada oma muret ning saada nõu. Enamjaolt küsitakse abi, sest postituse autor ei tea, kuhu või kuidas pöörduma peaks, seda eelkõige korduva seksuaalvägivalla puhul. Politseid pigem kardetakse või ei usaldata ja tuntakse muret, et politseisse pöördumisel saab juhtunu avalikku tähelepanu ning teised inimesed juhtunust teada.

Postitused, kus kirjeldati seksuaalvägivalda, mida ka filmiti või pildistati, väljendasid tugevamalt seonduvat häbitunnet, nagu näiteks alljärgnevas rekonstrueeritud tekstis:

Ma ei julge enam endale peeglis otsagi vaadata. Kui ma olen näiteks linnas, siis tunnen totaalset häbi, sest mul on selline tunne südames, et äkki see inimene oli seal... või siis äkki see inimene? Äkki tema filmis?

Digiplatvormidel lihtsalt jagatav (audio)visuaalne sisu võib mängida olulist rolli taasohvristamisel (re-victimization), kus kuritegu taasluuakse iga kord, kui seda materjali vaadatakse, modifitseeritakse või edasi jagatakse (Davidson 2008: 25).

Mõtlemapanev tähelepanek on see, et sageli teemaalgatuste autorid kirjeldavad põhjalikult juhtunut ning otsivad (ja mõnikord ka saavad) abi ja tuge, kuid valitsev diskursiivne raamistik paistab olevat see, et veebikommunikatsioon ei 
ole "päris" - teisisõnu, foorumis kirjutamist ei defineerita "ära rääkimisena", pigem on see justnagu hüppelauaks füüsilises maailmas abi otsimise ja mure jagamiseni.

Laste esmased sotsialiseerimisagendid ja turvatunde tagajad on üldjuhul lapsevanemad. See paistab välja ka analüüsitud postitustes, kus ema ja isa (just selles järjekorras!) on enamasti esimesed tegutsejad, keda abi otsimisel nimetatakse või loetletakse. Seksuaalvägivalla puhul on vanemate poole pöördumine keeruline, ja seda mitmel põhjusel. Olulised mõjurid on nii lapse suhted vanematega kui ka vanemate omavahelised suhted (Soo et al. 2016), näiteks ei ole võimalik abi saada, kui vanemad on üksteise või lapse vastu vägivaldsed või hoolimatud või põhjustab suhtlusbarjääri lapse soovimatus vanemaid kurvastada. Primaarsete sotsialiseerijate kõrval muutuvad oluliseks sekundaarsed (sõbrad, kool, meedia), lisaks on kõikvõimalikud seksuaalsusega seonduvad teemad paljuski, hoolimata diskursiivsest plahvatusest (Foucault 2005) endiselt stigmatiseeritud ning seostatud patuga.

Tõenäoliselt tähtsaimaks takistuseks on juhtunuga seostatav häbitunne, mis kaasneb enesesüüdistamisega. Häbitunne oli meie uuringus ilmsem neis postitustes, kus kirjeldati peresisest seksuaalvägivalda. Teistel juhtudel aga muretsesid veebifoorumisse postitajad enamasti, et vanemad hakkavad neid juhtunus süüdistama või ei usu neid. Viimast eelkõige siis, kui juhtunu leidis aset mõnda aega tagasi või kui postitaja rõhutas, et tal ei ole konkreetseid tõendeid.

\section{“Ma tean, et see on mu enda süü" - ohvrite enesesüüdistamine}

Suures osas valimisse kuulunud postitustest võis väga tugevalt märgata mitte kõhklust "kas mind usutakse / äkki hakkavad mind süüdistama", vaid juba internaliseeritud iseenda süüdistamist. See puudus vaid neist postitustest, mille sisu oli lakooniline kirjeldus (minuga juhtus) ja nõu ning abi otsimine (mida ma tegema peaksin). Ohvrite puhul leidus käitumuslikku süüdistamist (mida mina tegin) märkimisväärselt sagedamini kui karaktereoloogilist (milline ma olen). Viimast esines eeskätt viidetena oma noorusele ja rumalusele, aga ka enda füüsisele:

Ma olen sale, blondide juustega, ja rinnakas. Kahjuks just sellised mehi ligi tõmbavadki.

Domineeris käitumuslik süüdistamine, mille puhul ohvrid otsisid ja leidsid põhjuseid näiteks enda riietusest, alkoholitarbimisest ja mitte vastuhakkamisest, mõned rekonstrueeritud tekstinäited: 
Eks ma olen ise ka sü̈̈di, sest ma ei mõelnud üldse. Ma tahtsin hea välja näha, olin võrdlemisi napis riietuses, mul oli seljas lühike seelik ja pluus. See tegi neile asja lihtsaks. Äkki neile tuligi idee sealt.

Pärast seda kannan ma ainult naiste boksereid või hotpants-tüüpi aluspesu.

Ma olin natuke ise ka sü̈̈di, kuna ma kõndisin pimedas ja kõrvaklapid olid peas.

Aga ma oleksin ju võinud peksta ja karjuda. Keegi oleks ehk ikka kuulnud seda. Aga ma ei teinud nii, seega olen selles ise sü̈̈di.

Autorid ei süüdistanud ennast esialgses postituses enamasti peresiseste seksuaalvägivalla episoodide puhul ega siis, kui ohver oli juhtunu toimumise hetkel väga noor (alla kümneaastane).

Peale ohtra enesesüüdistamise ilmnes teinegi korduv (kuid teatud mõttes vastupidine) retooriline konstruktsioon. Ohvrid püüdsid esialgses postituses potentsiaalseid vastajaid veenda, et nad on korralikud ega võinud oma olemuse ja käitumisega juhtunut kuidagi ise põhjustada. Selline eristamine stiilis "ma pole selline, kellega seksuaalvägivald juhtuma peaks" teeb nähtavaks kogu vägistamismüütide tuuma - on olemas inimesed, kes on seksuaalvägivalda "väärt". Seega näeme foorumipostitustes mõnikord alateadlikku püüet presenteerida end kaheldamatult tõelise ohvrina, kes väärib kaastunnet:

Ta oli mu esimene poiss, kaks aastat vanem minust. Ja ma pole mingi lohakas, ma olen korralik ja eeskujulik õpilane ja pole probleemne...

Endale vastanduvana nähakse sellisel juhul stereotüüpi inimesest, kes on juhtunu ära teeninud ja kelle teisesus (Strömpl 2015; Kristeva 1991) konstrueeritakse iseendast võimalikult erinevana. Aga kuna kirjeldaja ise ei taju ennast seksuaalvägivalla stereotüüpse ohvrina, süvenevad ka kahtlused, kas juhtunu sai üldse olla seksuaalvägivald, kas peaks ja on võimalik abi saada.

\section{"Ma ei tea, kas see on üldse vägistamine" - ohvrite kõhklused juhtunu tõlgendamisel}

Foorumisse pöördusid ka noored, kes soovisid teada saada või kinnitust leida, kas nendega juhtunu üldse kvalifitseerub seksuaalvägivallaks või mitte. Üks näide sellisest postitusest:

Ma ei tea, kas see nü̈̈d on vägivald, aga mu poiss surus end mulle peale ükskord kui tema juures ööbisin. 
Seda esines just nende juhtumite puhul, kus toimepanija oli ohvri eakaaslasest partner, mis näitab, et vääruskumus, mille kohaselt paarisuhtes justkui ei saa seksuaalvägivald aset leida, on üks oluline müüdiloome ja stereotüüpide taasloome probleemkoht. Stereotüübi keskmest aimdub monogaamse ja lojaalse paarisuhte ülimuslikkuse tajumine ja kindel võimusuhte dünaamika, milles heteroseksuaalse paarisuhte meespoolel on teatud mõttes "defineerimisõigus". Selle tajutud sotsiaalne aktsepteeritavus teiste poolt paneb ohvreid kahtlema abisaamise võimalikkuses:

Ma ei tea, kas ma saan sellega politseisse või kuskile üldse minna, ta on ju mu kutt. See nagu teeb mulle haiget küll, et usaldust niimoodi rikkus.

Kuna sellistel juhtudel olid ohvrid toimepanijaga suhtes, selgitasid nad ka, millised olid seksuaalse lubatavuse piirid valitsenud suhtes varasemalt. Juhtunut raamistatigi pigem kui piiride ületamist või usalduse rikkumist, mitte kui vägivalda või kuritegu:

Me olime küll suudelnud ja üksteist puudutanud, aga ta teadis, et ma ei ole veel valmis. Ma hakkasin nutma ja palusin, et ta lõpetaks, aga ta ei lõpetanud enne kui...

No mõnda asja olime ikka varem ka teinud, aga ma ütlesin, et ei taha seda, ta ikka jätkas. Pärast kallistas ja hoidis mind nagu midagi poleks juhtunud. Aga ma tundsin nagu minus oleks lihtsalt üks suur tühimik.

Seega soovivad ohvrid küll abi ja tunnevad, et nendega juhtunu ei olnud õige, samas kõrvutavad endaga juhtunut aga nn päris vägistamistega. Üheks põhjuseks oli füüsilise vägivalla puudumine. Ka varasemates uuringutes on leitud, et mida jõhkram on kaasnev vägivald paarisuhtes toimunud seksuaalvägivalla puhul, seda suurem on tõenäosus, et ohver tõlgendab juhtunut vägistamisena (Martin et al. 2007). Samuti mõjutasid ohvrite ebakindlust juhtunu tõlgendamisel nende käsitlused traditsioonilistest soorollidest. Naissoost ohver tunneb pigem, et tal on alati kohustus oma partneriga vahekorras olla, mistõttu ei käsitleta juhtunut niivõrd tõsisena kui nn tavapäraseid vägistamisi (Martin et al. 2007). Tegu on kahjuliku väärarusaamaga justkui väheneks keha autonoomia suhtesse astumisega ning partneril tekiks õigus seksuaalvahekorda nõuda.

Kui esmasele, kompivale ja kõhklevale abi otsimisele järgnevad negatiivsed reaktsioonid (nt kahtlemine või süüdistamine), võivad tekkida olulised barjäärid edasistele püüdlustele abi otsida või väärkohtlemisest rääkida (Ahrens 2006). Usaldusisiku (ehk inimes(t)e, kellele laps väärkohtlemisest räägib) reaktsioon on selles protsessis keskse tähtsusega ning mängib olulist rolli ka väärkohtlemisest taastumisel (Reitsema \& Grietens 2016). Järgnevalt vaatlemegi, kuidas n-ö usaldusisikud internetifoorumis reageerivad. 


\section{Vastajate reaktsioonid seksuaalvägivalla kirjeldustele ja abipalvetele}

\section{“Pidid ikka päris loll olema” - ohvrisüüdistamise erinevad tahud}

Ohvri süüdistamist võib esineda mitmel viisil, muuhulgas juhtunut pisendades, võrreldes võrreldamatuid või võrdsustades ohvri ja toimepanija agentsust. Ohvri süüdistamise mõistmiseks võtsime aluseks Ronnie Janoff-Bulmani (1979) ohvrisüüdistamise tüpoloogia. Ka meie analüüsitavas materjalis esines nii karaktereoloogilist kui ka käitumuslikku süüdistamist, viimast aga tunduvalt sagedamini. Karaktereoloogiline omistamine keskendus aspektidele nagu ohvri karakter, välimus, isiksus või meelelaad. Alaealised tüdrukud "sattusid" foorumis osalejate hinnangul seksuaalvägivalla ohvriks seetõttu, et nad on liiga ekstravertsed, tähelepanujanus, rumalad, naiivsed (etteheitena ka väga noorte postitajate puhul) ja usaldavad:

Ma tahan nii väga Sind ja teisi ohvreid ja neid, kes ei ole veel midagi halba tunda saanud, ma tahan teid hoiatada, et te ometi inimesi ei usaldaks!

Käitumusliku omistamise keskne idee ütleb, et kui ohver oleks teisiti käitunud, olnud ettevaatlikum või ettenägelikum, oleks saanud seksuaalvägivalda vältida. Peamiselt on valeks käitumiseks peole või kellelegi külla minek, alkoholi tarvitamine, provokatiivselt riietumine, flirtimine, üksi pimedas koju jalutamine ja vastupanu osutamata jätmine. Ohvri käitumist demoniseeritakse ja konstrueeritakse hälbivana. Kõige sagedasem näide sellest repertuaarist väidab, et seksuaalne vägivald oleneb riietusest. Veebifoorumisse postitajate hinnangul vägistatakse suurema tõenäosusega neid, kes paistavad oma riietusega silma. Et vastustes rõhutati ohvri riietust või välimust, ei tähenda, nagu oleks ohver end alati esialgses postituses kirjeldanud. Mõnikord olid need pelgalt vastaja enda järeldused, näiteks kui seksuaalvägivald leidis aset peol, siis järeldati, et ohver oli väljakutsuvalt riides.

Ühelt poolt on tegu süüdistusega, mis üritab väita, et ohvril on võimalik valida või otsustada ohvriks langemise üle ja seksuaalvägivalla esinemise sagedus tema elus on tema enda kontrolli all. Teisalt sisaldavad sellised väited üldist ideoloogilist lähenemist, kus ei räägita teo toimepanija vastutusest, vaid kantakse vastutus üle ohvritele. Kolmas oluline asjaolu on sooline aspekt - just naiste langemine seksuaalvägivalla ohvriks sõltub riietusest või käitumisest või muudest valikutest. Ühes teemaalgatuses oli 13aastane ohver kirjutanud endaga juhtunust ning vastuses rõhutati just riiete (teadliku) valiku olulisust: 
See seksuaalne vägivald oleneb suuremas osas naise riietusest. Mida ekstravagantsem, seda suurem võimalus, et vägistatakse.

Märkimisväärselt sageli võis märgata otseselt ohvrit süüdistavates vastustes isegi parastavat tooni või otsesõnu parastamist:

Ise oled sü̈̈di ja siis nutad pärast, kui keegi vägistab. Miks te panete siis endale sellised riided selga, tissid paistavad välja ja aluspükste paelad pükstest väljas. Eriti stringid. Mina ütlen, et paras sulle.

Või näiteks juhtumi puhul, kus kümneaastane langes vägistamise ohvriks ning tüdrukut oli mõjutatud valmistama endast seksuaalset väärkohtlemist kujutavat materjali, ${ }^{1}$ kirjutas üks vastaja:

Ma jätaks küll juhtunu enda teada ja unustaks ära. Muidugi ma ise ei teekski midagi sellist. Pidid ikka ise väga-väga loll olema, ausalt öeldes.

Markantne on eelneva näite puhul käitumisviiside hüpoteetiline vastandamine ("kuidas mina käituksin, kuidas sina käitusid"). Vastaja püüab ohvrit iseendast eristada, tuues välja, et juhtunu on ohvri süü ning selle põhjustas ohvri rumalus, samas eraldi kinnitades, et tema on teistsugune ja seega ei saa temaga selliseid asju juhtuda. Näeme siin taas vastanduva stereotüübi jõulist esiletulekut, nagu on välja toodud ka ohvrite repertuaaride analüüsis.

Analüüsist selgus, et karakteroloogilise ja käitumusliku ohvrisüüdistamise puhul on oluline roll levinud stereotüüpide taasjutustamisel - ohver on ohver, sest ta lihtsalt on selline ja ta käitub teatud viisil. Mõnel juhul oli ohver tekstis taandatud üheplaanilisest stereotüübist lausa elutuks asjaks, metafoori otsimise käigus objektifitseeritud:

Ikka üsna loll peab olema. See on nagu jätaks kalli käekella autos nähtavale kohale ja auto uksed lukustamata. Ja siis pärast nutta politseile, et kell on ära varastatud.

On võimalik, et selline retooriline võte võimaldab postitajal kõnealusest teemast psühholoogiliselt distantseeruda ning mõelda kuriteost ja selle ohvritest kui abstraktsetest nähtustest.

Isegi ohvrisüüdistamise repertuaari sees pakkusid veebifoorumis osalejad omapoolseid soovitusi ja lahendusi, näiteks seksuaalvägivalla ennetamiseks tulevikus. See aga oli enamasti ohvrisüüdistamise pehmem versioon, kus rõhutati just ohvri agentsust. Need soovitused on koondunud mõtteviisi ümber, mille kohaselt on ohvri kohustus ennast kaitsta ning seksuaalvägivalla ennetamine tulevikus on samuti tema kontrolli all. Tavapäraselt soovitati "oma eluga edasi minna" või "oma elu kuidagi muuta". 
"Mine oma eluga edasi" tüüpi soovitustes julgustati ohvreid mitte alla andma, samas soovitades, et juhtunu tuleks lihtsalt ära unustada ja endale paksem nahk kasvatada. "Muuda oma elu" tüüpi soovitused olid kõige otsesemalt seotud ohvri vastutusega nii juhtunuga toimetulekul kui ka edaspidiselt seksuaalvägivalla ennetamisega. Suur osa nendest soovitustest keskendusid füüsiliste võimete ja heaolu arendamisele või vaimsele ja hariduslikule arengule:

Sa peaks õppima enesekaitset, et midagi sellist enam juhtuda ei saaks ja end kaitsta suudaksid.

Keskendu iseendale ja õppimisele. Mida paremad tulemused sul on kooli lõpetades, seda kiiremini saad kodust eemale, näiteks mine õppima mingit elukutset ja siis saad minna tööle ja iseseisva elu peale, kus keegi sind ei ahista.

Veel rõhutati ohvritele, et n-ö kohustuslikus korras peaks harjuma kaasas kandma kindlaid tooteid ja esemeid, mis aitaksid vägistajaid eemale peletada, näiteks nimetati kääre, pipragaasi, sääsetõrjevahendit ja lõhnaõli. "Muuda oma elu" tüüpi soovituste kõige ekstreemsemad näited soovitasid ohvril toimepanija naabrusest ära kolida (toimepanija oli eakaaslasest naaber) või kooli vahetada (toimepanija oli klassikaaslane).

\section{“See pole ju tema süü” - toimepanija õigustamine}

Kui eelnevas alapeatükis nägime ohvrite süüstamist, siis nüüd vaatleme, kuidas seksuaalvägivalla toimepanijaid samasuguste stereotüüpidel põhinevate retooriliste võtetega süüst vabastati. Valdavalt esines vastajatel kolme tüüpi väiteid, mis püüdsid seksuaalvägivalda normaliseerida või legitimiseerida. Kui võtta kokku postitajate väljendatud seisukohad alkoholi tarvitamise osas, siis paradoksaalselt on alkohol ohvrite puhul raskendav ning teo toimepanijate puhul kergendav (kui mitte isegi täielikult vabandav) asjaolu:

Ise oled sü̈̈di, et ennast nii vastutustundetult täis jõid ja ära kasutada lasid. Muidugi see polnud temast kena, et ta sind niimoodi ära kasutas, aga nagu ma su jutust aru saan, oli temagi täis ega saanud päris hästi aru, mida ta teeb.

Siinkohal on seksuaalvägivalda raamistatud pigem kui ebaviisakat või amoraalset tegu, mitte kui vägivalda. Sageli tõstatati küsimus, mil määral sai toimepanija aru, kas nõusolek vahekorraks oli olemas või mitte. Vastuhakkamist peeti üheks eelduseks, et tegu oleks käsitletav seksuaalvägivallana, selle 
puudumisel olevat vastajate sõnul ka toimepanijal keeruline aru saada, kas nõusolek on olemas või mitte.

Oota, aga kui sa vastu ei hakanud, siis see ei ole ju seksuaalne vägivald või vägistamine? Äkki see tü̈̈p arvas, et sa oled lihtsalt vähekogenud ja tegelikult asjaga nõus?

Samas ei peeta mõnel puhul aga selgesõnalist nõusoleku otsimist oluliseks, pigem on tegemist ebamugava "protseduurireegliga", mida järgida ei taheta ja seeläbi on taas vastutus ohvrile lükatud:

Võib olla see poiss arvas, et sa ka tahad. Niimoodi otse öelda, et "seksime!" on ju nõme. Ma ise alustan ka vaikselt ja ei küsi niimoodi otse, ja päriselt, tüdrukutele paistab see meeldivat.

Siit joonistub välja vastajate üldine käsitlus seksuaalvahekorraks nõusoleku tuvastamisest - oodatakse selgelt väljendatud keeldumist ("ei" ütlemist) või vastuhakkamist, mitte arusaadavat nõustumist. ${ }^{2}$

Võib selgelt näha, kuidas vastajad taastoodavad erinevatest osapooltest kahjulikke kuvandeid, mis toetavad seksuaalvägivalla aktsepteerimist, õigustamist ja normaliseerimist. Tüdrukuid kuvandatakse kui passiivsemaid osapooli, keda tuleb veenda seksuaalvahekorraga nõustuma või lihtsalt alustada sõltumata nõusolekust, sest vastajate sõnul tüdrukud mängivadki raskesti kättesaadavat. Samal ajal poisid ongi stereotüübi kohaselt aktiivsemad ja domineerivamad osapooled, kuid selge nõusoleku saamine ei kuulu selle aktiivsuse alla.

Alkoholijoobe ja nõusolekuga seonduvate toimepanijat õigustavate argumentide kõrval esines ka kolmas aspekt, mis vastajate hinnangul toimepanija tegusid selgitab (ja mõnikord lausa õigustab) - “poisid ongi sellised”. Seksuaalse agressiooni raamistamine normaalseks seksuaalkäitumiseks või maskuliinsuse loomulikuks osaks oli toimepanija tegude õigustamisel tavapärane. Samal ajal kuvandatakse ohvreid (siin kontekstis tüdrukuid) kui isikuid, kes vastutavad vastassoo seksuaalsuse kontrollimise eest (Burt \& Estep 1981).

Kusjuures, laste ja alaealiste tüdrukute rekontseptualiseerimine ja ümbernimetamine noorteks naisteks oli vaatlusaluses foorumis väga levinud võte vastutuse ohvrile suunamiseks ja olukorra tõsiduse pisendamiseks. Täiesti vastupidiselt aga nimetati ründajaid sageli "poisteks" (mitte noormeesteks või meesteks), justnagu rõhutades nende vanust:

See oleneb ka sellest, kuidas sa käitud, kui sa ikka seksikalt vaatad otsa ja käitud nagu sa tahaks saada, siis võib ju arvata, et see tõmbab poisse ligi. 
See pole küll kuidagi poisi süü, äkki tema jaoks oli juba tema juurde minek väike vihje või midagi?

Politseisse pöördumist soovitati hoolega kaaluda või isegi vältida peamiselt siis, kui toimepanija oli ohvri eakaaslane või eakaaslasest partner. Suurema vanusevahe puhul oli toimepanija vastajate hinnangul rohkem karistust väärt. Samas vaadeldi eakaaslaste puhul juhtunut pigem noore inimese eksimuse, mitte vägivallana.

Kui ta juba oma sugulase käest kõvasti peksa sai selle asja eest, siis on õppetund ju saadud, äkki sai aru, et nii ei tohi teha ja sul pole vaja politseisse pöörduda. Kui sa siiski lähed, siis sa rikud küll ta elu alatiseks ära. Eks sa muidugi ise tead, mis teed, see on ju sinu otsustada.

Kuigi otsese ohvrisüüdistamise puhul ei nähtunud, et meessoost vastajad oleksid ohvreid enam süüdistanud kui naissoost vastajad, oli soolise aspekti mõju repertuaarides siiski olemas. Olemasoleva informatsiooni põhjal saab viidata tendentsile, et seksuaalvägivalla toimepanijat õigustavad ja tema käitumist normaliseerivad sagedamini meessoost isikud, naissoost foorumikasutajad annavad pigem nõu seoses võimaliku seksuaalvägivalla ennetamisega tulevikus (nt kuidas oma käitumist muuta või mida teisiti teha) või toetavad ja julgustavad abi otsijat (sama on leidnud ka nt Kahn et al. 2011). Statistika kohaselt (Soo et al. 2016; Ahven et al. 2019) on väga suurel osal naistest ning tüdrukutest seksuaalvägivallaga isiklik kokkupuude, mistõttu on üks tõenäoline selgitus veebifoorumi jälgijate ja postitajate poolt tajutud sarnasus ja samastumine ohvri või toimepanijaga ehk näide kausaalse atributsiooni teooria ilmnemisest meie empiirilises materjalis.

\section{“See nüüd küll väga reaalne ei tundunud" - tõelise ohvri konstrueerimine}

Ohvrites kahtlemise puhul on tegu vastajate hoiakute ja seisukohtadega, mille kohaselt peaks ohver käituma, suhtuma ja/või ennast väljendama teatud viisil ning nimetatud stereotüübist kõrvale kaldudes ta kas: (a) valetab; või (b) ta ei ole saanud selliselt kahjustada nagu tõeline ohver "olema peaks". Samuti ei käsitleta tõelise ohvrina neid, kes veebifoorumis osalejate hinnangul olid juhtunus ise süüdi.

Kõige tüüpilisem viis ohvri postitus kahtluse alla seada toimub stiilis "kui ongi tõsi, siis...". Vaadeldud veebifoorumis on üheks domineerivaks võtteks väitmine, et ohver valetab, tuues välja kas tema isiku või juhtunu detailidega 
seotud asjaolusid. Valdavalt oli tegu vastajate hinnanguga sellele, millised "reaalsed vägistamissituatsioonid" nende hinnangul välja näevad. Nagu leidis Kerstin Adolfsson (2018), esines ka meie uuringus seda, et ei usutud ohvreid, keda vägistati grupiviisiliselt:

Kammoon, see on ju feik. Et mitu inimest vägistas kordamööda? See on sama hea kui öelda, et "aa, mul siin just surid isa ja onu ja vanaisa korraga ära”.

Ebareaalseks vägistamiskogemuseks peeti ka ülima detailsusega meenutatavaid kogemusi ("sest traumasid ei mäletata ju”; "mida laps ikka mäletab”) ning ajaliselt kaua kestvate seksuaalvägivallajuhtumite kirjeldusi:

No see poiss pidi küll kõva kestvusega olema, et kohe suutis nii hästi, terve tunni sü̈̈tu tüdrukuga vastu pidada. Mind on ka vägistatud, aga vägistaja ei suutnud üle paari minuti vastu pidada. Ja mul mõned tuttavad ka vägistatud, samamoodi üle viie mintsa ei pidanud vastu. Sattusime vist kehvade vägistajate otsa.

Kui enamasti võivad inimeste arusaamad seksuaalvägivallast ja vägistamistest olla tugevalt vahendatud ja mõjutatud meediarepresentatsioonidest, siis näeme eelnevast illustreerivast näitest, et iseenda kogemus võib samuti olla diskursust ankurdavaks teadmiseks. Kõnealuses näites oli ka rekonstrueeritud tsitaadi aluseks olevas originaalvastuses kõnekalt kasutatud väärtushinnanguid stiilis "suutis hästi" ning "kehv vägistaja", mille puhul viitab postitaja tõenäoliselt sarkastiliselt pornostunud (Paasonen 2016) arusaamadele, mida kantakse üle ka seksuaalvägivallale.

Teine muster ohvrites kahtlemisel oli seotud sellega, kuidas tõeline ohver abi otsiks või juhtunut kirjeldaks.

Ükski tegelik vägistamisohver ei räägi niimoodi pisiasju kirjeldades, mida temaga tehti ja ei kasuta selliseid väljendeid.

Vägistamisohvrid räägivad tavaliselt sellest mis juhtus täiesti eemalseisja positsioonist, kliiniliselt.

Vastajate sõnul on olemas spetsiifiline viis, kuidas ohvrid juhtunust räägivad ja ennast kirjeldavad. Ohvri sõnavaliku tõttu kas kaheldi väidete tõelevastavuses või hinnati, et ohver ei paista olevat nii tugevalt kahjustada saanud (nagu üks vägistamisohver olema peaks).

Postitustes, kus ohver toimepanijat tundis, kaheldi rohkem kui nendes, kus toimepanija oli ohvrile võõras. Peresiseste juhtumite puhul usuti pigem neid, kes olid lapseealised või polnud vanuse (või arusaamisvõimetuse) tõttu võimelised 
vastupanu osutama (nt vanaisa poolt rünnatud teismelise ohvri puhul kaheldi, et kuidas kiire ja tugev nooruk ei suuda vanale inimesele vastu hakata).

Seisukoht, milles veebifoorumis osalejad tundusid olevat ühel meelel, on vastuhakkamise vajadus, ja seda peetakse isegi eelduseks, et juhtunu üldse kvalifitseeruks seksuaalvägivallana.

No kuidas sa said üldse lasta tal ennast vägistada? Ta ei olnud ju sinust nii palju suurem ja tugevam, ju sulle endale ikka natuke ka meeldis.

Vastuhakkamise teemadel arutledes jõudsid foorumis osalejad järeldusele, et kui ohver enda eest kõige täiega ei võitle või vastu ei hakka, siis ei pruugigi tegemist olla tahtevastase tegevusega. Mitmel korral jõuti detailsete aruteludeni sellest, kui palju ohver ja ründaja kaaluvad ja kas ohvril oleks olnud füüsiliselt võimalik võidelda ja vastu hakata, kui ta "lihtsalt/päriselt oleks tahtnud". Ekstreemsemate vastuhaku näidetena toodi välja hammustamist ("sa oleks võinud tal peenise küljest hammustada"), suguelunditesse sihitud hoope ("oleks pidanud munadesse lööma”) või muude füüsiliste enesekaitsevõtete kasutamist.

Lisaks levis vastajate seas üsna palju eksiarvamusi selles osas, millised teod klassifitseeruvad kuritegudeks ning kuidas kriminaalmenetlust läbi viiakse. Seksuaalvägivalla puhul väljendati politsei osas usaldamatust enam kui usaldust. Vastajad arutasid veebifoorumis, kas konkreetse juhtumi puhul on piisavalt asitõendeid ja millised asitõendid oleksid piisavad, et politseisse pöörduda. Leidus ka viiteid sellele, et tegemist on üldlevinud ja aktsepteeritud diskursusega, mis võib vähendada ohvrite usku ja lootust abi saamisesse ning toimepanijate karistamisse:

Selliste vägistamiste kohta öeldakse politseis lihtsalt et libud jõid end purju.

Et võtta erinevad stereotüübid kokku - lähtudes vastajate reaktsioonidest on nn tõeline ohver selgelt lapseealine (näiteks viieaastane). Vanuseliselt oodatakse analüüsitud tekstide puhul juba kümneaastastelt, et nad oleksid võimelised mõistma võimalikku seksuaalvägivallariski ning aru saama sellest, kui kellelgi on kavas neid ära kasutada. Tõeline ohver ei ole alkoholijoobes ega situatsioonis, kus alkoholi tarvitatakse. Ohvrit rünnatakse kas tema enda kodus või koduteel. Toimepanija puhul on tegu pigem võõra vanema mehega, noorte toimepanijate puhul on tegu pigem probleemsest perest pärit vägivaldsete noortega. Toimunu leiab aset pigem ühekordse episoodina ning lisaks seksuaalvägivallale kasutatakse ka muud vägivalda, mis põhjustab ohvrile nii valu kui reaalseid vigastusi ning "legitimiseerib" seeläbi ohvri staatust. Tõelisel ohvril on juhtunu kohta ka mingisugused asitõendid, nagu näiteks vigastused või videosalvestis. 
Juhtunut kirjeldades ja abi otsides on tõeline ohver pigem emotsionaalne (nt väljendab seda, et ta nutab), elab juhtunut väga raskelt läbi ja tunneb hirmu.

Meie uuringu valimisse kuulunud postitustes oli ainult neli tõelise ohvri stereotüübile vastavat postitust ning vaid kolm ohvrit pöördusid tagasi foorumisse, tänasid teisi ning jagasid, et nad said abi. Need kolm ohvrit vastasid tõelise ohvri stereotüübile ning nende puhul olid vastajad eranditult toetavad, kinnitanud ohvrile, et see pole tema süü, julgustanud abi otsima ning andnud ka konkreetseid juhtnööre, kuidas seda teha. Seega leidis kinnitust Anne Margit Reitsema ja Hans Grietensi (2016) kirjeldatud efekt usaldusisiku(te) reaktsiooni osatähtsusest abi saamise protsessis - need, keda julgustatakse ja toetatakse, julgevad rääkida ja saavad vajalikku abi. Ning need, keda ei usutud ja keda süüdistati, selle uuringu raames kättesaadavate andmete kohaselt abi ei saanud. ${ }^{3}$

\section{Kokkuvõte}

Käesolevas uuringus selgus, et abi saamine sõltus sellest, kas ohver sobitus tõelise ohvri stereotüübi raamidesse või mitte. Tõelise ohvri konstrueerimise kõrval joonduvad välja ka arusaamad tõelisest toimepanijast (võõras vanem mees, vägivaldne jne) ning ka reaalsest vägistamissituatsioonist (vägivaldne ja pigem vigastusi põhjustav, pimedas eraldatud kohas, ajaliselt kestab paar minutit jne). See tähendab, et peale selle, et meil on olemas vägistamise (ja seksuaalvägivalla) juriidiline definitsioon, eksisteerib inimeste jagatud (väär) arusaamades ka seksuaalvägivalla sotsiaalne (ühiskondlik) käsitlus.

Vägistamise sotsiaalne definitsioon põhineb erinevatel valikuliselt kohaldatud vägistamismüütidel ja ühiskondlikel normidel, näiteks soorollide ja seksuaalsusega seotud stereotüüpidel. Nii seksuaalvägivalla käsitlemine "tõelisena" kui ka ohvristaatuse omistamine või ümberlükkamine on sotsiaalsed konstruktsioonid. Üks näide sellest on vägistamise ümberformuleerimine konsensuslikuks vahekorraks, klassifitseerides vägivalda ja agressiivsust kui normaalset osa maskuliinsusest ning kuvandades ohvrit naiivse ja rumalana (naiselikkus). Veel üks levinud retooriline ohvristaatuse pisendamise võte on tunnistamine, et sunnitud vahekord küll toimus, kuid seejärel juhtunu tähtsuse vähendamine või teadlik rekontekstualiseerimine. Seda toetatakse sageli väidetega, et ohver ei saanud küllalt tõsiseid vigastusi või kahjustusi, on juhtunus ise süüdi või ei vääri muul põhjusel kaastunnet (Anderson \& Doherty 2007). Siia alla kuulub ka arusaam, et paarisuhtes ei saa olla vägistamist, sest sellises suhtes on nõusolek kogu aeg olemas. 
Tavapäraselt räägitakse agentsusest või toimevõimest kui positiivsest - inimeste vabast tahtest, loovusest ja võimest muuta (repressiivseid) sotsiaalseid struktuure (Giddens 1984; Wiggins \& Bowers 2014). Meie uuringus väljajoonistunud stereotüüpides ja vägistamismüütides näeme aga teatud mõttes kõverpeegli-agentsust. Selle all peame silmas seda, et seksuaalvägivalla kontekstis on akti algataja toimevõimet pisendatud ning ohvri agentsust esitatakse just vastupidi, võimendatuna. Seksuaalvägivallatseja allub "kontrollimatutele" ihadele, ei suuda ega pea otsima nõusolekut ning on passiivsena kuvandatav olukordades, kus ohvrile on omistatud äraspidine agentsus, mis väljendub aktiivse tegutseja määratlemises verbide tasandil - laseb end ära kasutada, pakub välja, ahvatleb, rikub oma ohvriks sattumisega kellegi elu ära.

Tulemuste peatükis kirjeldatud diskursused ja tõlgendusrepertuaarid näitavad, kuivõrd võimsad ja tõsiste tagajärgedega võivad olla müüdid ja stereotüübid. Siinses uuringus vaatlesime keelekasutust kui seksuaalvägivallaga seotud diskursuste taastootmise ja kinnistamise olulist osa, sotsiaalse praktika vormi, mis on määratletud sotsiaalsete struktuuride poolt (Fairclough 1989: 22-27). Argises kontekstis võib see ehk märkamatuks jääda, kuid vaadeldes ühiskonnas levivate diskursuste mõju nii üksikisikutele kui ka erinevatele kollektiividele, siinkohal veebifoorumi kasutajatele, on nende samade ajalooliskultuuriliselt kujunenud müütide ja stereotüüpide jõud vaieldamatult tugev. ${ }^{4}$ Käesolev uurimus illustreerib ilmekalt seda, kuidas üks sotsiaalne müüt töötab ning kuidas seda väikeste interaktsioonide kaudu ikka ja jälle taas üles ehitatakse ja tugevdatakse. ${ }^{5}$

\section{Tänuavaldus}

Autorid tänavad artikli valmimisele kaasa aitamise eest Judit Strömplit, Veronika Kalmust, Dagmar Kutsarit, Kadri Sood ning põhjalikke ja toetavaid retsensente. 


\section{Kommentaarid}

1 Kuigi lapsporno(graafia) on siiani laialdaselt kasutatav termin ning esineb ka juriidilise terminoloogiana õigussüsteemis, tuleks (vähemalt mittejuriidilises) kontekstis selle asemel eelistada mõistet "lapse seksuaalset väärkohtlemist kujutav materjal" (ingl CSAM - child sexual abuse material). Seksualiseeritud materjal, mis kujutab või muul viisil esindab lapsi, on laste seksuaalse väärkohtlemise üks vorm, sellisel materjalil on kujutatud kuriteo ohvreid ja seega ei tohiks seda käsitleda pornograafiana (Greijer \& Doek 2016).

${ }^{2}$ Arusaadava nõustumise (affirmative consent) all mõtleme nõusoleku kontseptsiooni, mis peegeldab "jah tähendab jah" lähenemist. See tähendab, et osapooled peaksid veenduma selles, et mõlema arusaadav ja vabatahtlik nõusolek seksuaaltegevus(t)eks on olemas, mitte ootama keeldumist või vastu hakkamist "ei tähendab ei" stiilis lähenemise järgi. Nõnda jääks ära vaidlus selle üle, kuidas tõlgendada kellegi "ei" ütlemist või keeldumist.

3 Seksuaalvägivallast rääkimine on keeruline ja üldjuhul mitmeosaline protsess. Nii personaalse(te) usaldusisiku(te) kui anonüümsemate veebikogukondade liikmete reaktsioon - aga sealjuures muidugi mõjuritena ka laiemad ühiskondlikud diskursused seksuaalvägivallast - mõjutavad ohvri enda käsitlusi oma kogemustest, enesesüüdistamist, abiotsimise protsessi ning taastumist. Arvestades, et ka lapsi, kes seksuaalvägivalla all kannatavad, ennekõike süüdistatakse ega usuta, on arusaadav, miks abi otsimine on niivõrd raske ja valulik. Ehkki täna on Eestis olemas teenused, mis võiksid ohvritele adekvaatset nõu ja abi pakkuda (näiteks lasteabi telefon, lastemaja teenus), mõjutavad ühiskondlikud diskursused ka nende teenusteni jõudmist. Lapsed on tundlikud teiste reaktsioonide suhtes, mistõttu täiskasvanute abi on oluline nii juhtunust rääkimisel, selle käsitlemisel, abisaamisel kui ka oma emotsioonidega toimetulekul.

4 Abstraktse "avalikkuse" teadlikkuse tõstmise eesmärgi kõrval on tundlike teemade käsitlemiseks kasutatavate keskkondade puhul oluline roll just platvormi haldajal, kes võimaldab nii platvormi kasutamist kui erinevate diskursiivsete praktikate taastootmist ja legitimeerimist. Just platvormi võimaldajal on võimalus olla diskursuse suunaja ning toetada (uute) positiivsete praktikate kujunemist. Laste ja noortega tegelevatele spetsialistidele tuleks tutvustada seksuaalvägivallaga soetud tüüpilisi internaliseeritud väärarvamusi ja vägistamismüüte, et ka nemad saaksid kaasa aidata uute praktikate kujundamisele.

5 On oluline esile tuua, et töö üheks piiranguks on asjaolu, et valimi moodustasid ainult naissoost ohvrite postitused, valimist jäid välja nii meessoost ohvrid kui ka transinimesed. Meeste langemist seksuaalvägivalla ohvriks on veel keerulisem tuvastada, sest ühiskondlik stigma ja ohvrisüüdistamine on meeste puhul enamasti kõrgem kui naiste puhul. Seega võiksid need olla edasiste uuringute fookuspunktid. 


\section{Kirjandus}

Adolfsson, Kerstin 2018. Blaming Victims of Rape: Studies on Rape Myths and Beliefs about Rape. Dissertation. University of Gothenburg, Department of Psychology.

Ahrens, Courtney E. 2006. Being Silenced: The Impact of Negative Social Reactions on the Disclosure of Rape. American Journal of Community Psychology 38 (3-4), lk 31-34 (doi: 10.1007/s10464-006-9069-9).

Ahven, Andri \& Kruusmaa, Kätlin-Chris \& Leps, Anu \& Solodov, Stanislav \& Surva, Laidi \& Sööt, Mari-Liis \& Tamm, Kaire \& Tammiste, Brit \& Tüllinen, Krister 2019. Kuritegevus Eestis 2018. Tallinn: Justiitsministeerium.

Alaggia, Ramona \& Collin-Vézina, Delphine \& Lateef, Rusan 2019. Facilitators and Barriers to Child Sexual Abuse (CSA) Disclosures: A Research Update (2000-2016). Trauma, Violence, \& Abuse 20 (2), lk 260-283 (doi: 10.1177/1524838017697312).

Anderson, Irina 1999. Characterological and Behavioral Blame in Conversations About Female and Male Rape. Journal of Language and Social Psychology 18 (4), lk 377-394 (doi: 10.1177/0261927X99018004002).

Anderson, Irina \& Doherty, Kathy 2007. Accounting for Rape. Psychology, Feminism and Discourse Analysis in the Study of Sexual Violence. London \& New York: Routledge.

Ayala, Erin E. \& Kotary, Brandy \& Hetz, Maria 2018. Blame Attributions of Victims and Perpetrators: Effects of Victim Gender, Perpetrator Gender, and Relationship. Journal of Interpersonal Violence 33 (1), lk 94-116 (doi: 10.1177/0886260515599160).

Basow, Susan A. 1992. Gender: Stereotypes and roles. Thomson Brooks/Cole Publishing Company.

Bian, Lin \& Leslie, Sarah-Jane \& Cimpian, Andrei 2017. Gender Stereotypes About Intellectual Ability Emerge Early and Influence Children's Interests. Science 355 (6323), lk 389-391 (doi: 10.1126/science.aah6524).

Braun, Virginia \& Clarke, Victoria 2006. Using Thematic Analysis in Psychology. Qualitative Research in Psychology 3 (2), lk 77-101 (doi: 10.1191/1478088706qp063oa).

Burt, Martha R. \& Estep, Rhoda E. 1981. Who Is Victim? Definitional Problems in Sexual Victimisation. Victimology 6, lk 15-28.

Davidson, Julia 2008. Child Sexual Abuse: Media Representations and Government Reactions. Abingdon, Oxon: Routledge-Cavendish.

Davies, Michelle \& Rogers, Paul \& Whitelegg, Lisa 2009. Effects of Victim Gender, Victim Sexual Orientation, Victim Response and Respondent Gender on Judgements of Blame in a Hypothetical Adolescent Rape. Legal and Criminological Psychology 14 (2), lk 331-338 (doi: 10.1348/978185408X386030).

Edwards, Derek \& Potter, Jonathan 1992. Discursive Psychology 8. Sage.

Eesti Seksuaaltervise Liit 2014. Seksuaalvägivalla-alased hoiakud Eestis. Eesti Seksuaaltervise Liit, Turu-uuringute AS (http://www.estl.ee/admin/upload/ Dokumendid/2014\%2012\%20Seksuaalv\%C3\%A4givald\%20ESTL\%202014.pdf 4. märts 2020). 
Eesti Statistikaamet 2019. IT32: 16-74-aastased arvuti- ja internetikasutajad isikute rühma järgi [statistika andmebaas] (http://pub.stat.ee/px-web.2001/dialog/varval.asp? ma=IT32\&ti=16\%2D74\%2DAASTASED+ARVUTI\%2D+JA+INTERNETIKASUTAJAD +ISIKUTE+R\%DCHMA+J\%C4RGI\&path=../database/Majandus/05Infotehnoloogia/04 Infotehnoloogia_leibkonnas/\&search=INTERNET\&lang=2 - 4. märts 2020).

Euroopa Liidu Põhiõiguste Amet 2014. Naistevastane vägivald: Euroopa Liitu hõlmav uuring. Tulemuste kokkuvõte (https://fra.europa.eu/sites/default/files/fra-2014-vawsurvey-at-a-glance-oct14_et.pdf - 4. märts 2020).

Fairclough, Norman 1989. Language and Power. London \& New York: Longman.

Filipas, Henrietta H. \& Ullman, Sarah E. 2001. Social Reactions to Sexual Assault Victims from Various Support Sources. Violence and Victims 16 (6), lk 673-692.

Fiske, John 2010. The John Fiske Collection: Introduction to Communication Studies. Routledge.

Foucault, Michel 2005. Seksuaalsuse ajalugu. 1. Teadmistahe. Tallinn: Valgus.

Franklin, Courtney A. \& Menaker, Tasha A. 2015. The Impact of Observer Characteristics on Blame Assessments of Prostituted Female Youth. Feminist Criminology 10 (2), lk 140$164(10.1177 / 1557085114535234$ - 4. märts 2020).

Friesen, Norm 2017. Confessional Technologies of The Self: From Seneca to Social Media. First Monday. Peer-reviewed Journal on the Internet (doi: 10.5210/fm.v22i6.6750).

Gibbs, Graham R. 2015. Discourse Analysis Part 1: Discursive Psychology. From a lecture by GR Gibbs: The University of Huddersfield (videoloeng: https://www.youtube.com/ watch?v=F5rEy1lbvlw - 4. märts 2020).

Giddens, Anthony 1984. The constitution of society: Outline of the theory of structuration. University of California Press.

Gravelin, Claire R. \& Biernat, Monica \& Bucher, Caroline E. 2018. Blaming the Victim of Acquaintance Rape: Individual, Situational, and Sociocultural Factors. Frontiers in psychology 9 (22), art 2422 (doi: 10.3389/fpsyg.2018.02422).

Greeson, Megan R. \& Campbell, Rebecca \& Fehler-Cabral, Giannina 2016. "Nobody Deserves This": Adolescent Sexual Assault Victims'perceptions of Disbelief and Victim Blame from Police. Journal of Community Psychology 44 (1), lk 90-110 (doi: 10.1002/ jcop.21744).

Greijer, Susanna \& Doek, Jaap 2016. Terminology Guidelines for the Protection of Children from Sexual Exploitation and Sexual Abuse. Adopted by the Interagency Working Group in Luxembourg, 28 January 2016. Luxembourg: ECPAT Luxembourg, ECPAT International (http://uxembourgguidelines.org/wp-content/uploads/2017/06/ Terminology-guidelines-396922-EN.pdf - 5. märts 2020).

Grubb, Amy \& Harrower, Julie 2008. Attribution of Blame in Cases of Rape: An Analysis of Participant Gender, Type of Rape and Perceived Similarity to the Victim. Aggression and Violent Behavior 13 (5), lk 396-405 (doi: 10.1016/j.avb.2008.06.006). 
Hammond, Elizabeth M. \& Berry, Melissa A. \& Rodriguez, Dario N. 2011. The Influence of Rape Myth Acceptance, Sexual Attitudes, and Belief in a Just World on Attributions of Responsibility in a Date Rape Scenario. Legal and Criminological Psychology 16 (2), lk 242-252 (doi: 10.1348/135532510X499887).

Howard, Judith A. 1984. Societal Influences on Attribution: Blaming Some Victims More Than Others. Journal of Personality and Social Psychology 47 (3), lk 494-505 (doi: 10.1037/0022-3514.47.3.494).

Janoff-Bulman, Ronnie 1979. Characterological Versus Behavioral Self-Blame: Inquiries into Depression and Rape. Journal of Personality and Social Psychology 37 (10), lk 17981809 (doi: 10.1037//0022-3514.37.10.1798).

Kahn, Arnold S. \& Rodgers, Kimberly A. \& Martin, Charley \& Malick, Kiah \& Claytor, Jamie \& Gandolfo, Maria \& Seay, Rebecca \& McMillan, Jacklyn R. \& Webne, Ellen 2011. Gender Versus Gender Role in Attributions of Blame for a Sexual Assault. Journal of Applied Social Psychology 41 (2), lk 239-251 (doi: 10.1111/j.1559-1816.2010.00711.x).

Karistusseadustik 2001 = Karistusseadustik. Vastu võetud 06.06.2001. Riigi Teataja I, 2001, 61, 364 (https://www.riigiteataja.ee/akt/184411 -5. märts 2020).

Kivisalu, Kaidi-Lisa 2019. \#Metoo Movement in Estonia: A Frame Analysis. Magistritöö. Tartu Ülikool, Johan Skytte poliitikauuringute instituut (https://dspace.ut.ee/ handle/10062/64242? show=full -5 . märts 2020).

Kloppen, Kathrine \& Haugland, Siren \& Svedin, Carl Göran \& Mæhle, Magne \& Breivik, Kyrre 2016. Prevalence of Child Sexual Abuse in the Nordic Countries: A Literature Review. Journal of Child Sexual Abuse 25 (1), lk 37-55 (doi: 10.1080/10538712.2015.1108944).

Krahé, Barbara \& Temkin, Jennifer \& Bieneck, Steffen \& Berger, Anja 2008. Prospective Lawyers' Rape Stereotypes and Schematic Decision Making About Rape Cases. Psychology, Crime and Law 14 (5), lk 461-479 (doi: 10.1080/10683160801932380).

Kristeva, Julia 1991. Strangers to ourselves. Columbia University Press.

Kurs, Sandra 2018. Seksuaalse ahistamise kriminaliseerimise vajalikkusest eesti õigussüsteemis. Magistritöö. Tartu Ülikool, avaliku õiguse instituut (http://hdl.handle. net/10062/60074 - 5. märts 2020).

Lerner, Melvin J. \& Matthews, Gail 1967. Reactions to Suffering of Others Under Conditions of Indirect Responsibility. Journal of Personality and Social Psychology 5 (3), lk 319-325 (doi: 10.1037/h0024304).

Lerner, Melvin J. \& Miller, Dale T. 1978. Just World Research and The Attribution Process: Looking Back and Ahead. Psychological Bulletin 85 (5), lk 1030-1051.

Lips, Hilary M. 2017. Sex and gender: An introduction. Long Grove (Ill): Waveland Press. London, Kamala \& Bruck, Maggie \& Wright, Daniel B. \& Ceci, Stephen J. 2008. Review of the Contemporary Literature on How Children Report Sexual Abuse to Others: Findings, Methodological Issues, and Implications for Forensic Interviewers. Memory 16 (1), lk 29-47 (doi: 10.1080/09658210701725732). 
Macrae, C. Neil \& Stangor, Charles \& Hewstone, Miles (toim) 1996. Stereotypes and Stereotyping. New York: Guilford Press.

Mann, Chris \& Stewart, Fiona 2000. Internet Communication and Qualitative Research: A Handbook For Researching Online. Sage (doi: 10.13140/RG.2.1.4278.5768).

Markham, Annette 2012. Fabrication as Ethical Practice: Qualitative Inquiry in Ambiguous Internet Contexts. Information, Communication \& Society 15 (3), lk 334-353 (doi: 10.1080/1369118X.2011.641993).

Martin, Elaine K. \& Taft, Casey T. \& Resick, Patricia A. 2007. A review of marital rape. Aggression and Violent Behavior 12 (3), lk 329-347 (doi: 10.1016/j.avb.2006.10.003).

McElvaney, Rosaleen \& Greene, Sheila \& Hogan, Diane 2014. To Tell or Not to Tell? Factors Influencing Young People's Informal Disclosures of Child Sexual Abuse. Journal of Interpersonal Violence 29 (5), lk 928-947 (doi: 10.1177/0886260513506281).

McKenzie, Pamela J. 2005. Interpretive Repertoires. Fisher, Karen E. \& Erdelez, Sanda \& McKechnie, Lynne (E.F.) (toim). Theories of Information Behavior: A Researcher's Guide. Medford, NJ: Information Today, lk 221-224.

McKimmie, Blake M. \& Masser, Barbara M. \& Bongiorno, Renata 2014. What Counts as Rape? The Effect of Offense Prototypes, Victim Stereotypes, and Participant Gender on How the Complainant and Defendant Are Perceived. Journal of Interpersonal Violence 29 (12), lk 2273-2303 (doi: 10.1177/0886260513518843).

Minn, Marelle 2018. Seksuaalse väärkohtlemisega seotud hoiakud Eesti noorte hulgas. Bakalaureusetöö. Tartu Ülikool, Ühiskonnateaduste instituut.

MTO 2013 = Maailma Terviseorganisatsioon 2013. Global and regional estimates of violence against women: Prevalence and Health Effects of Intimate Partner Violence and Non-Partner Sexual Violence. Italy: WHO publication.

Nelson, Amanda 2019. Understanding Fear and Self-Blame Symptoms for Child Sexual Abuse Victims in Treatment: An Interaction of Youth Age, Perpetrator Type, and Treatment Time Period. Undergraduate Honors Thesis. University of Nebraska-Lincoln.

Paal, Robert 2019. Alaealiste vastane lähisuhtevägivald - seksuaalvägivallajuhtumite menetlemise probleemkohad Eestis. Magistritöö. Tartu Ülikool, karistusõiguse osakond.

Paasonen, Susanna 2016. Pornification and the Mainstreaming of Sex. Oxford Research Encyclopedia of Criminology and Criminal Justice. Oxford University Press (doi: 10.1093/ acrefore/9780190264079.013.159).

Patel, Meghna Nalinkumar 2009. Why Do We Blame Victims of Sexual Assault? Dissertation. St. Louis: University of Missouri.

Payne, Diana L. \& Lonsway, Kimberly A. \& Fitzgerald, Louise F. 1999. Rape myth acceptance: Exploration of its structure and its measurement using the Illinois rape myth acceptance scale. Journal of Research in Personality 33 (1), lk 27-68 (doi: 10.1006/ jrpe.1998.2238). 
Pickering, Michael 2007. Stereotyping and stereotypes. Ritzer, George (toim). The Blackwell encyclopedia of sociology. Malden \& Oxforf \& Carlton: Blackwell Publishing Ltd (doi: 10.1002/9781405165518.wbeoss263).

Potter, Jonathan \& Wetherell, Margaret 1987. Discourse and Social Psychology: Beyond Attitudes and Behaviour. London: Sage Publications.

Potter, Jonathan 1996. Representing Reality: Discourse, Rhetoric and Social Construction. London: Sage Publications.

Reitsema, Anne Margit \& Grietens, Hans 2016. Is Anybody Listening? The Literature on the Dialogical Process of Child Sexual Abuse Disclosure Reviewed. Trauma, Violence, \& Abuse 17 (3), lk 330-340 (doi: 10.1177/1524838015584368).

Reynolds, Aimee 2017. The Effects of Rape Myth Acceptance and Gender Role Beliefs on Perceptions of Date Rape. Undergraduate project. Liverpool: John Moores University (https://e-space.mmu.ac.uk/id/eprint/619248 - 5. märts 2020).

Schuller, Regina A. \& McKimmie, Blake M. \& Masser, Barbara M. \& Klippenstine, Marc A. 2010. Judgments of Sexual Assault: The Impact of Complainant Emotional Demeanor, Gender, and Victim Stereotypes. New Criminal Law Review. An International and Interdisciplinary Journal 13 (4), lk 759-780 (doi: 10.1525/nclr.2010.13.4.759).

Shaver, Kelly G. \& Drown, Debra 1986. On Causality, Responsibility, and Self-Blame: A Theoretical Note. Journal of Personality and Social Psychology 50 (4), lk 697-702 (doi: 10.1037/0022-3514.50.4.697).

Sherman, Steven J. \& Sherman, Jeffrey W. \& Percy, Elise J. \& Soderberg, Courtney K. 2016. Stereotype Development and Formation. Carlston, Donald E. (toim). Oxford Library of Psychology. The Oxford Handbook of Social Cognition. New York, NY, US: Oxford University Press, lk 548-574 (doi: 10.1093/oxfordhb/9780199730018.013.0027).

Socio 2016 = Seksuaalvägivalla alased hoiakud ning teadlikkus. Uuring Eesti Seksuaaltervise Liidu tellimusel. Socio uuringukeskus (http://www.estl.ee/admin/upload/ Dokumendid/20160428_ESTL_raport.pdf - 5. märts 2020).

Soo, Kadri 2006. Kodune kasvatusatmosfäär ja nooruki probleemkäitumine-seksuaalse väärkohtlemise risk. Magistritöö. Tartu Ülikool, sotsioloogia ja sotsiaalpoliitika osakond (http://hdl.handle.net/10062/835 - 6. märts 2020).

Soo, Kadri \& Laanpere, Made \& Lippus, Hedda \& Part, Kai 2015. Seksuaalvägivalla levimus ja hoiakud Eestis: uuringute ülevaade. Tartu: Eesti Seksuaaltervise Liit (http:// www.estl.ee/admin/upload/Dokumendid/SVV_ULEVAADE_EESTIS_2015.pdf - 6. märts 2020).

Soo, Kadri \& Lukk, Maarika \& Ainsaar, Mare \& Beilmann, Mai \& Tamm, Gerly \& Espenberg, Kerly \& Murakas, Rein \& Arak, Triinu \& Aksen, Merli \& Vahaste-Pruul, Sille \& Kutsar, Dagmar 2016. Laste ja noorte seksuaalse väärkohtlemise leviku uuring. Tartu: Tartu Ülikool (https://www.kriminaalpoliitika.ee/et/laste-ja-noorte-seksuaalsevaarkohtlemise-leviku-uuring-2015 - 6. märts 2020). 
Stewart, Mary White \& Dobbin, Shirley A. \& Gatowski, Sophia I. 1996. "Real Rapes" and "Real Victims": The Shared Reliance on Common Cultural Definitions of Rape. Feminist Legal Studies 4 (2), lk 159-177 (doi: 10.1007/BF02167608).

Stone, Ellen A. \& Brown, Christia S. \& Jewell, Jennifer A. 2015. The Sexualized Girl: A Within-Gender Stereotype Among Elementary School Children. Child Development 86 (5), lk 1604-1622 (doi: 10.1111/cdev.12405).

Strömpl, Judit 2015. Online Risks: Adapting an Interactive Dialogical Narrative Method to the Study of the Process of Meaning Making by Teenagers. Allaste, AiriAlina \& Tiidenberg, Katrin (toim). “In Search of...”: New Methodological Approaches to Youth Research. Cambridge Scholars Publishing, lk 194-215.

Strömwall, Leif A. \& Alfredsson, Helen \& Landström, Sara 2013. Rape Victim and Perpetrator Blame and the Just World Hypothesis: The Influence of Victim Gender and Age. Journal of Sexual Aggression 19 (2), lk 207-217 (doi: 10.1080/13552600.2012.683455).

Sun, Chyng \& Bridges, Ana \& Johnson, Jennifer A. \& Ezzell, Matthew B. 2016. Pornography and the male sexual script: An analysis of consumption and sexual relations. Archives of sexual behavior 45 (4), lk 983-994 (doi: 10.1007/s10508-014-0391-2).

Taliväting, Margo 2018. Elusündmuste küsimustiku kohandamine eesti keelde ja traumakogemuste hindamine psühhoosihaigetel. Magistritöö. Tartu Ülikool, psühholoogia instituut (https://dspace.ut.ee/handle/10062/61329 - 6. märts 2020).

Talts, Maarja 2013. Alaealiste seksuaalse väärkohtlemise viktimoloogia. Magistritöö. Tartu Ülikool, õigusteaduskond (https://dspace.ut.ee/handle/10062/32028 - 6. märts 2020).

TNS EMOR 2014. Eesti elanikkonna teadlikkuse uuring soopõhise vägivalla ja inimkaubanduse valdkonnas. TNS Emor, EV Sotsiaalministeerium (http://ft.ee/admin/ upload/files/Elanike\%20hoiakud\%20soop\%C3\%B5hise\%20v\%C3\%A4givalla\%20ja\%20 inimkaubanduse\%20valdkonnas2014_aruanne_TNS\%20Emor_1\%C3\%B5plik.pdf 6. märts 2020).

TNS EMOR 2016. Eesti elanikkonna teadlikkuse uuring soopõhise vägivalla ja inimkaubanduse valdkonnas 2016. TNS Emor, EV Sotsiaalministeerium (https://www. sm.ee/sites/default/files/content-editors/Ministeerium_kontaktid/Uuringu_ja_analuusid/ soopohise_vagivalla_uuring_2016_aruanne_emor_loplik.pdf - 6. märts 2020).

Touart, Bianka 2013. Lapse seksuaalne väärkohtlemine ja selle mõju ohvri hilisemale elule ning ennetamis- ja sekkumisvõimalused. Lõputöö. Tartu Ülikool, sotsiaaltöö korralduse osakond (http://hdl.handle.net/10062/32602 - 6. märts 2020).

Van der Bruggen, Madeleine \& Grubb, Amy 2014. A Review of the Literature Relating to Rape Victim Blaming: An Analysis of the Impact of Observer and Victim Characteristics on Attribution of Blame in Rape Cases. Aggression and Violent Behavior 19 (5), lk 523-531 (doi: 10.1016/j.avb.2014.07.008).

Ward, Colleen A. 1995. Attitudes Toward Rape: Feminist and Social Psychological Perspectives 8. Sage Publications. 
Wiggins, Bradley E., \& Bowers Bret G. 2015. Memes as genre: A structurational analysis of the memescape. New Media \& Society 17 (11), lk 1886-1906 (doi: 10.1177/1461444814535194).

Wolitzky-Taylor, Kate B. \& Resnick, Heidi S. \& Amstadter, Ananda B. \& McCauley, Jenna L. \& Ruggiero, Kenneth J. \& Kilpatrick, Dean G. 2011. Reporting Rape in a National Sample of College Women. Journal of American College Health 59 (7), lk 582-587 (doi: 10.1080/07448481.2010.515634).

Yamawaki, Niwako 2009. The Role of Rape Myth Acceptance and Belief in a Just World on Victim Blame Attribution: A study in Japan. Psychologia 52 (3), lk 163-174 (doi: 10.2117/psysoc.2009.163).

\title{
Summary
}

\section{"If it is true, then it is your own fault": Recurring stereotypes about sexual violence in an Estonian children's online forum}

\author{
Simone Eelmaa \\ Doctoral student in sociology \\ Institute of Social Studies, University of Tartu \\ simone.eelmaa@ut.ee \\ Maria Murumaa-Mengel \\ Lecturer in social media \\ Institute of Social Studies, University of Tartu \\ maria.murumaa@ut.ee
}

Keywords: child sexual abuse, rape myths, sexual violence, stereotypes, victim-blaming

This article provides an overview of how children and young people who are victims of sexual violence seek help and support from online forums, and the reactions and responses following such posts. Also, we look at how rape myths and stereotypes affect both the victims' and respondents' attitudes towards sexual violence, victim-blaming, and help-seeking. The analysis is based on 28 original forum posts about personally experienced sexual violence and 361 reactions to these original posts. At the time of the abuse the victims were between the ages of 5 and 17. By combining discursive psychological methodology with qualitative thematic analysis, we were able to distinguish six dominant interpretative repertoires, three dominant repertoires from the victims' posts (trying to start a dialogue, self-blaming, and uncertainty on recognizing intimate partner rape) and three from respondents' reactions (victim-blaming, justifying the perpetrator, and the stereotype of the "ideal victim").

For children and young people in our sample, the observed internet forum was mainly a starting point to gain courage and guidance for seeking help offline (e.g., telling one's 
mother or reporting abuse to the police). Victims often attributed behavioural selfblame (Janoff-Bulman 1979) to themselves. Intimate partner rape by a peer was often categorized as a betrayal of trust or crossing the boundaries but seldom as a crime. Underaged victims of intimate partner rape showed more characterological blame than other victims.

The most common reaction to victims' posts was victim-blaming, mainly behavioural blaming associated with clothing, alcohol consumption, and (not) resisting the abuse/ violence. Victims below the age of ten and victims of intrafamilial sexual abuse were not blamed. The ideology of the "ideal victim" played a pivotal part in the respondents' reactions and in the observable outcome for the victim. "Ideal victims" were approached with empathy, support, and adequate guidance, in contrast to the victims who diverged from the "ideal victim" stereotype and were blamed, shamed, insulted, and rarely guided to further action. The only victims who got the help they expected (e.g., were able to tell someone or report the crime) were the ones conforming with the "ideal victim" stereotype.

When children disclose sexual abuse, the reactions of others are critical determinants of whether the child gets the needed help and support or is silenced. These reactions of others do not include only blaming and shaming but also redefining the experience and the victim status. Rape was often redefined to something less, sometimes even to the extent of the act being normalised as if it was just normal sexual interactions or maybe "sex gone wrong". Sexual aggression was portrayed as a normal part of male masculinity, and female victims were portrayed as naive and stupid, but at the same time as flirtatious and deviant "gate-keepers" of male sexuality. Interestingly, perpetrator behaviour was justified with the same rhetorical tools as victims were blamed; for instance, intoxicated victims were attributed more blame, yet intoxicated perpetrators were justified or even exonerated of blame.

In this study, we looked at language use as an important part of reproducing and perpetuating rape myths and negative stereotypes surrounding sexual violence. This study highlighted how strong rape myths and stereotypes are, and how these are reproduced and reinforced through small everyday interactions over and over again.

Simone Eelmaa (MA, rahvusvaheline õigus ja inimõigused) on Tartu Ülikooli sotsioloogia doktorant ja teadustöö assistent Tartu Ülikooli õigusteaduskonnas. Tema peamised uurimisvaldkonnad on kuritegevus, vangistus, seksuaalvägivald, inimkaubandus ja seksuaalse sisuga veebiriskid.

Simone Eelmaa (MA, international law and human rights) is $\mathrm{PhD}$ student in sociology and research assistant at the School of Law, University of Tartu. Her main research fields include crime, imprisonment, sexual violence, human trafficking, and online sexual risks.

simone.eelmaa@ut.ee 
Maria Murumaa-Mengel ( $\mathrm{PhD}$, meedia ja kommunikatsioon) on Tartu Ülikooli ühiskonnateaduste instituudi sotsiaalmeedia lektor. Tema peamised uurijahuvid on seotud noorte veebikommunikatsiooniga, spetsiifilisemalt võimaluste (nt mikrokuulsuse fenomen; online-intiimsus) ja riskidega (nt küberkiusamine, pornograafia ja online-perverdid), mis seonduvad onlinekeskkondade ja suhtlusega.

Maria Murumaa-Mengel ( $\mathrm{PhD}$, media and communication) is lecturer in social media at the Institute of Social Studies, University of Tartu. Her main research interests are related to young people's online communication, more specifically the opportunities (e.g. microcelebrity, online intimacy) and risks (e.g. cyber harassment, pornography, online perverts).

maria.murumaa@ut.ee 